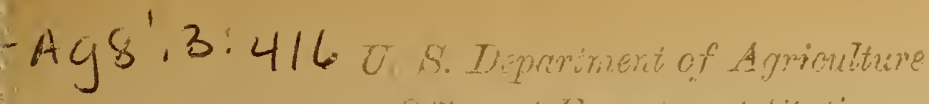

Bulletin 416

\title{
The Use of Fertilizer in the Coniferous Nursery \\ WITH SPECIAL REFERENCE TO PINUS RESINOSA
}

\author{
HERBERT A. LUNT
}

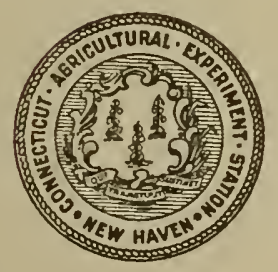

Uommectiont

EAgrimulturat Tixpreriment Station

Bieu thauen 



\title{
The Use of Fertilizer in the Coniferous Nursery
}

WITH SPECIAL REFERENCE TO

PINUS RESINOSA

\author{
HERBERT A. LUNT
}

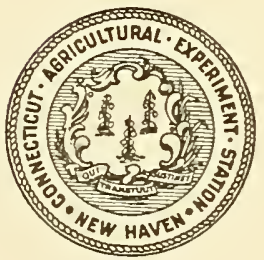

Uammertiont

Antricultural Fisperintent Station

Divut Igatuen 


\section{CONTENTS}

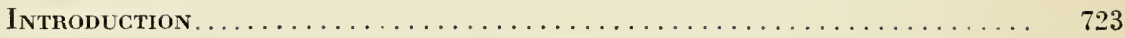

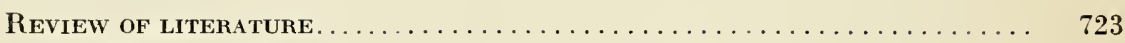

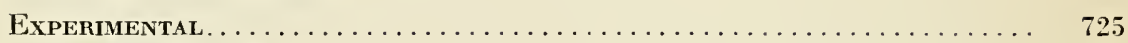

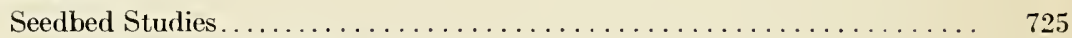

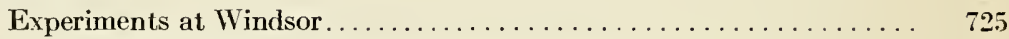

Seedbed Fertilization at Peoples Forest Nursery . . . . . . . . . 731

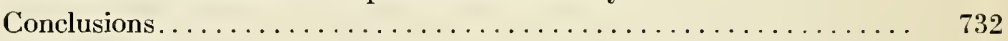

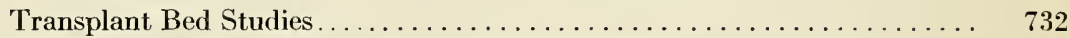

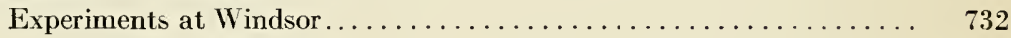

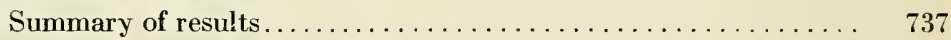

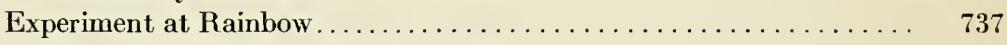

Experiments at Peoples Forest Nursery ................. 741

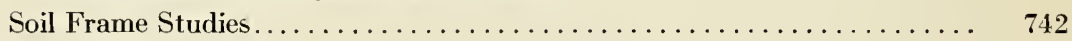

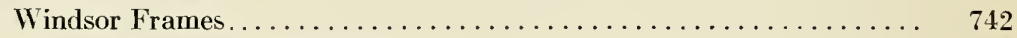

Station Frames at New Haven...................... 745

Subsequent Response of Red Pine in the Field............... 748

Requirements of Nursery Seedlings and Transplants............ 751

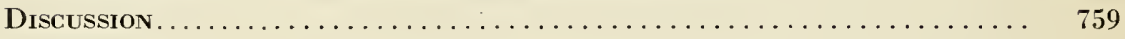

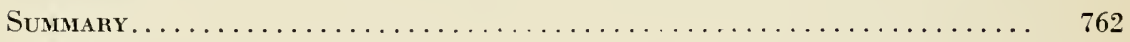

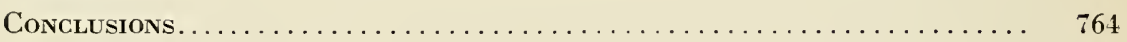

References Citen . . . . . . . . . . . . . . . . . . . . . . . . . $\quad 765$ 


\title{
THE USE OF FERTILIZER IN THE CONIFEROUS NURSERY
}

\author{
With Special Reference to Pinus resinosa
}

\author{
HERBERT A. LUNT
}

\section{$\mathbf{T}$}

HE DEMAND for forest nursery stock has been greatly accelerated in recent years by the agitation for tree-planting as a phase of soil conservation and flood control. In addition, the need of reforestation from the standpoint of timber and pulp wood production is becoming increasingly urgent. Without a doubt, tree planting for all three purposes will continue indefinitely as a permanent feature of the Nation's conservation program. Hence, the demand for nursery stock will be maintained at a higher level than it was prior to the present decade.

From the standpoint of the soil, we are faced with two problems: (a) increasing the productive capacity of old nurseries, and (b) maintaining the productive capacity of new ones; and this in the face of a diminishing supply and increasing cost of farm manure. Furthermore, it has been felt that some methods should be devised which would shorten the period of time normally considered necessary for the stock to remain in the nursery and which would also furnish larger, more thrifty plants, better able to survive when set out in the field. Whether this can best be accomplished by wider spacing, by root pruning, by fertilization, or by some other means is an important question confronting the nurseryman.

In some instances continued cropping, together with the scarcity of manure, has created a real need for the use of commercial fertilizers in order to produce trees of average size, to say nothing of larger stock. As will be brought out later, continuous cropping to nursery stock constitutes a serious drain on the soil, and satisfactory results cannot be expected unless plant food is added in the form of manure or commercial fertilizers or both and, in addition, a more or less systematic rotation of crops is practiced. Many nurserymen are aware of the situation and follow a very commendable system for the maintenance of the fertility of the soil. Others, equally desirous of keeping up soil fertility, for some reason do not succeed, and they are faced with the problem of finding a remedy or moving their beds to other fields that are in a good state of fertility.

\section{REVIEW OF LITERATURE}

Experiments in soil management in the forest nursery go back at least 65 years. Von Schroeder (19) cites the work of Dulk on Scotch pine, Norway spruce and beech in 1874 and 1875, and of Schüsse on pine and spruce in 1872, 1879 and 1882. From his own experiments von Schroeder concluded among other things that, in the second year, spruce requires about as much nitrogen as does lupine and red clover, and more phosphorus than red clover. 
Rather extensive researches by Vater early in the present century were published between 1905 and 1909 (26). For the succeeding 20 years his research on the subject of forest tree nutrition and fertilization has continued with greater emphasis on the forest than on nursery stock.

Among other European investigators who have worked on this problem may be mentioned Helbig, 1910 (2); Schwappach, 1916 (20); Kuhnert, 1930 (5); Leiningen-Westerburg, 1930 (6); Deines, 1930 (1); Manchard, 1933 (7); Némec, 1932-38 (10), (11), (12), (13), (14), (15), (17), (18); Sörensen, 1936 (21); Süchting, Jessen and Maurmann, 1937 (23); and Wetzel, 1937 (29). Materials most commonly used in fertilizer work in Europe are: ammonium sulfate, sodium nitrate, calcium nitrate, urea, Thomas slag, bonemeal, kainit, muriate and sulfate of potash, burnt lime and marl. Basalt meal is being tried as a fertilizer (3) with apparent success, especially as a supplement to manure to which it is added in the compost pile.

In this country experience in nursery fertilization is rather limited, although in recent years there have been quite a number of contributions on the subject. The earlier work up to 1931 was adeguately reviewed by Toumey and Korstian (25). They emphasize the importance of maintaining the organic matter content of the soil, since in producing nursery stock nothing is left or returned to the soil. They state that "farm manures are the most useful fertilizers for general purposes that can be used in nursery practice either alone or in combination with other materials composted with them". For commercial fertilizers they recommend the use of organic fertilizer such as dried blood, ground fish, tankage, etc., at the rate of 500 to 1500 pounds per acre, applied on seedbeds prior to planting, or as a top dressing, at the beginning of the second year. The senior author had good results in growing successive crops of coniferous seedlings on sandy loam, by applying in alternate years prior to preparation of the seedbeds the following: cow manure, 10 to 30 tons, per acre; bonemeal, 250 to 4.00 pounds; unbleached hardwood ashes, 400 to 800 pounds. After preparation of the beds and just prior to seeding, similar amounts of bonemeal and ashes were worked into the surface soil. The authors mention that in Europe some areas have been cropped to nursery stock continuously for 70 years. Fertility is maintained by using a compost of moor soil, ashes and nursery stock.

McIntyre and White (8), working with Norway spruce, pitch pine and white pine, reported that "in nearly all cases the seedlings grown on fertilized soil were larger, better developed and heavier than those grown on the checks". In some cases dried blood produced the largest seedlings; in other cases phosphorus; in still others LNPK (lime, nitrogen, phosphorus, potassium).

Extensive experiments at the Savenac Nursery in Montana (28) with Engelmann spruce (Picea engelmannii) and western yellow pine (Pinus ponderosa) indicated a definite improvement in the rate of growth with the use of fertilizers. With the spruce, at least a year was saved over the five or six-year period formerly necessary to produce sizable seedlings. Dried blood and bonemeal or large amounts of sheep manure seemed to be most effective. The pines were benefited most by a lawn-dressing type of fertilizer analyzing 4.6 percent nitrogen and 8.8 percent phosphoric 
acid. A blood-and-bone mixture was second best and sulfate of ammonia third.

Wilde (32) found that coniferous nursery stock was definitely benefited by the application of fertilizers, provided the right amount was used. Fertilized plants were better able to withstand heat and drought than those unfertilized. Wilde further reports (30) (31) that certain kinds of forest duff constitute ideal fertilizing material, although, because of the impracticability of using sufficiently large amounts to meet the needs of the nursery stock, it is necessary to use commercial fertilizers in addition. For stimulating stunted or otherwise handicapped plants, he recommends the use of liquid humate.

Although one finds, as he peruses the literature, conflicting reports as to the results of fertilization in the nursery, it is apparent by and large that nursery stock does respond to feeding. This is more erident in recent years, especially in this country, as a result, no doubt. of more carefully controlled experiments. The field of tree nutrition is only now beginning to be investigated and the possibilities for the future are most promising.

Our studies in nursery-soil management and seedling nutrition are by no means finished; but it seems expedient to publish as a progress report the findings obtained so far.

\section{EXPERIMENTAL}

At the suggestion of Mr. H. W. Hicock, Assistant Forester at the Station, experimentation was started in 1929 to determine whether there is any way either to shorten the period necessary for a seedling to remain in the nursery, or to obtain larger plants in the usual period of time. Red pine was chosen because at that time it was being planted to a much greater extent than any other species.

In a preliminary experiment in butter tubs, red pine seedlings were grown in four soils, ranging from a coarse, infertile sand to a well-fertilized, loamy sand tobacco soil. The results, given in Table 1 and Figures 108 and 109 , show that red pine is responsive to differences in fertility, particularly where the roots are confined as they were in this case.

\section{SEEDBED STUDIES}

\section{Experiments at Windsor}

A series of fertilizer experiments were carried out in seedbeds at the Windsor nursery over a period of six years. The soil was Merrimac loamy sand, rather well supplied with available phosphorus as a residue from previous treatment. It was low in potash, nitrogen and organic matter. Physically it was essentially the same as the soil in tub No. 4 of the preliminary butter tub experiment (Table 1). The rainfall averaged 46 inches, well distributed throughout the year. 


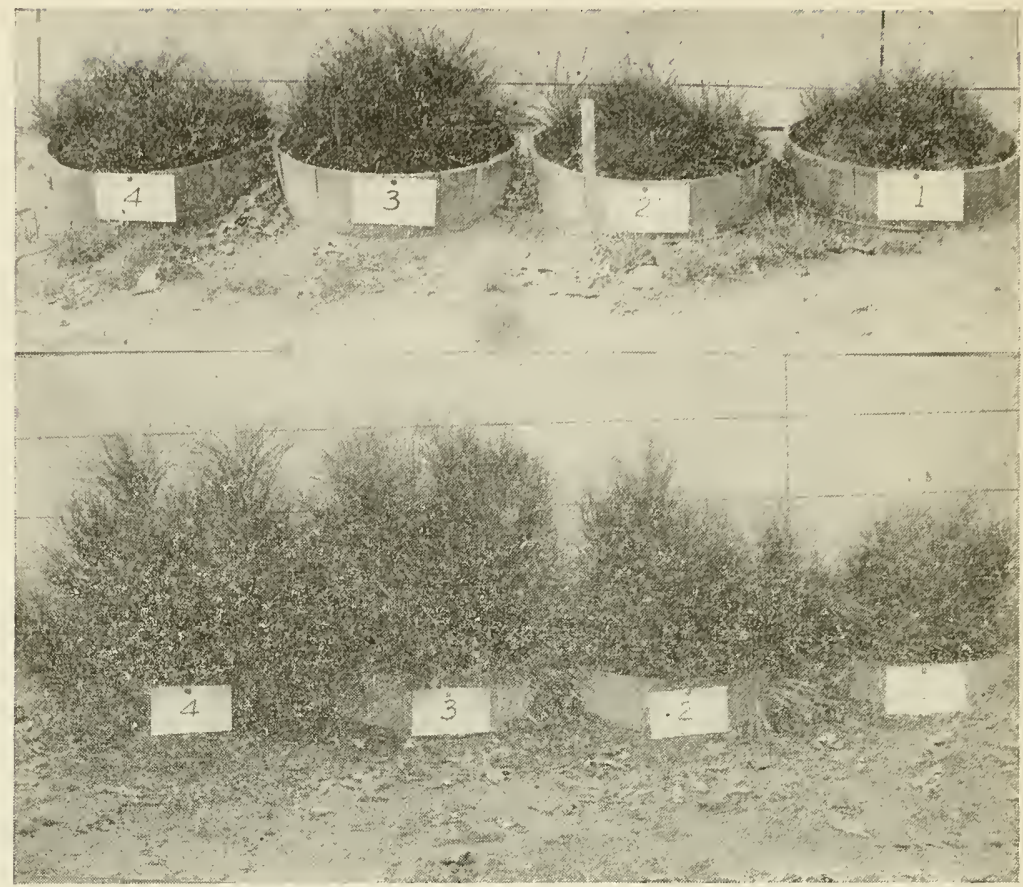

Figure 108. Response of red pine seedlings to soil fertility. Tub 1, very coarse, infertile sand; Tub 2, medium sand from red pine plantation; Tub 3, medium sand from fertilized tobacco field; Tub 4, highly fertilized loamy sand tobacco soil. Seed planted May, 1929. Upper: May 1932, Lower: April 1933.

To give full details of each experiment would require more space than the results warrant. Suffice to say that the materials used at one time or another, either alone or in combination, included the following, in pounds per acre:

\begin{tabular}{|c|c|c|c|}
\hline Ammonium sulfate & 240 & Potassium sulfate & 188 \\
\hline Bloodmeal & 500 & Precipitated bone & 325 \\
\hline Castor pomace & 2000 & Sodium nitrate & 1320 \\
\hline Driconure $^{1}$ & 19600 & Sorbex $^{5}$ & \\
\hline Fish meal & 300,600 & Tankage, bone & 2400 \\
\hline Hyperhumus ${ }^{2}$ & 16335 & Urea & $55,110,220$ \\
\hline Limestone, ground & 4000 & $6-8-7^{6}$ & 1325 \\
\hline Milorganite $^{3}$ & $400,800,1110$ & $11-6-6$ & 200,400 \\
\hline Nitrophoska (15-30-15 & 15) 333,1000 & $19-12-12$ & 433 \\
\hline Organic mixture $^{4}$ & 350,700 & $20-8-8$ & $100,200,2$ \\
\hline
\end{tabular}

${ }^{1}$ Driconure - Trade name for a mixture of cow manure and peat moss (the latter used as beddiug) dried and pulverized

${ }^{2}$ Hyperhumus - Trade name for a cultivated peat.

Milorganite-Trade name for an activated sewage sludge.

${ }^{4}$ Organic mixture-Cottonseed meal 40 parts, castor pomace 20 , precipitated bone 6 , and potassium sulfate 4 .

${ }^{5}$ Sorbex-Trade name for a screened peat moss.

${ }^{6} 6-8-7$ - Cottonseed meal 25 parts, castor pomace 25, potassium nitrate 15 , superphosphate $(16 \%)$ 30 , and Ammophos "A" (13-47-0) 5.

11-6-6-Fish meal 48 parts, ammonium sulfate 35, precipitated bone 6 , and potassium sulfate 11 .

19-12-12-Equal parts of urea, Ammophos "A", cottonseed meal and potassium nitrate.

20-8-8-Ammophos "A" 16.6 parts, urea 20.8, nitrate of soda 47.5 and potassium sulfate 15.1 . 


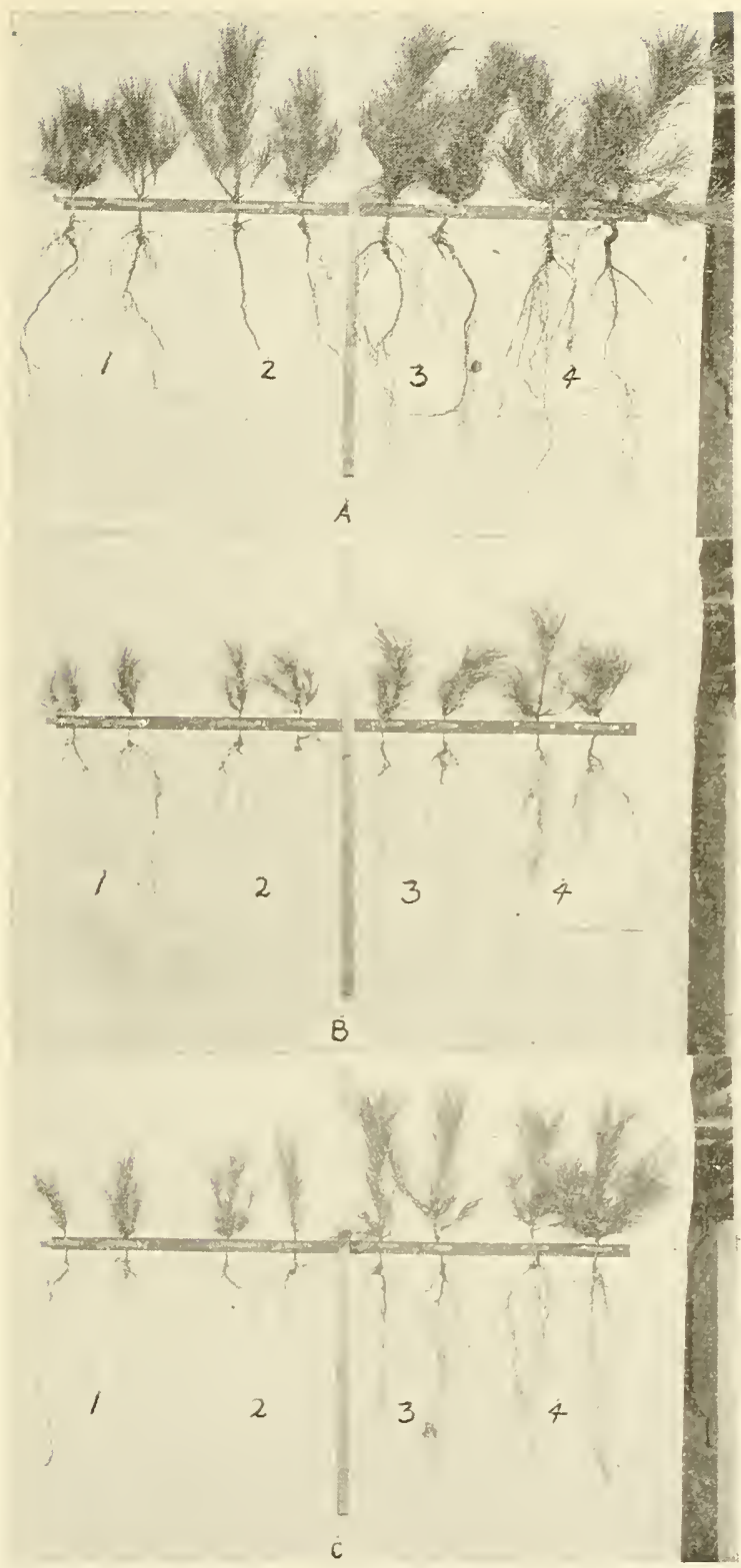

Figure 109. Comparison of plants from the four soils described in figure 108.
A. The two largest plants from each tub.
B. The two smallest plants from each tub.
C. Two average plants from each tub. 
Table 1. Data Relative to Soll Fertility Experiment with Red Pine Seedlings Grown in Butter Tubs

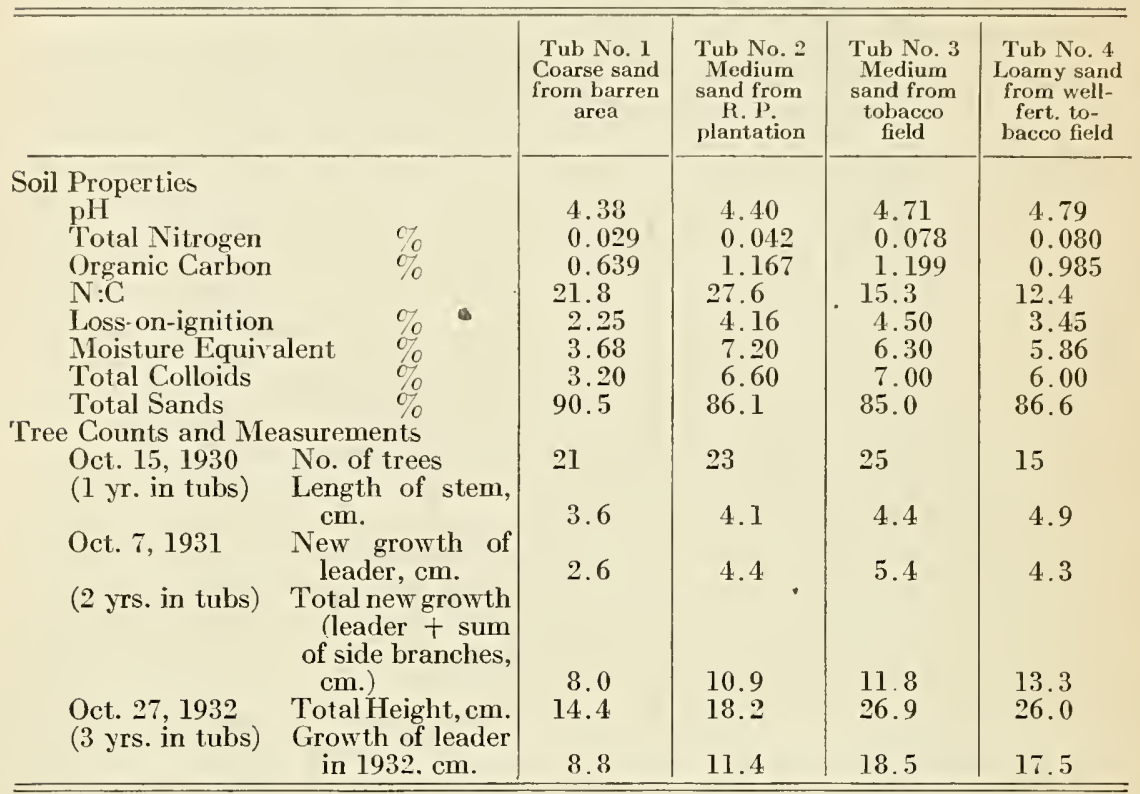

Table 2. Dry Weight and Needle Length of

Red Pine Seedlings Following Two Seasons' Growth

Fertilizers were applied prior to second season only

\begin{tabular}{|c|c|c|c|c|c|c|}
\hline \multirow{2}{*}{$\begin{array}{l}\text { Plot } \\
\text { No. }\end{array}$} & \multirow[b]{2}{*}{ Treatment } & \multicolumn{3}{|c|}{ Dry weight 100 plants } & \multicolumn{2}{|c|}{ Needle Length } \\
\hline & & g. & Av. & Relative & mm. & Av. \\
\hline 12 & Peat moss $+20-8-8$ & 22.6 & 22.6 & 169 & 82.2 & 82.2 \\
\hline $\begin{array}{r}3 \\
13\end{array}$ & $\begin{array}{l}\text { Fish } \\
\text { Fish }\end{array}$ & $\begin{array}{l}25.6 \\
17.6\end{array}$ & 21.6 & 161 & $\begin{array}{l}61.5 \\
55.0\end{array}$ & 58.3 \\
\hline $\begin{array}{l}6 \\
8 \\
4\end{array}$ & $\begin{array}{c}20-8-8 \\
6-17-13 \\
15-30-15\end{array}$ & $\begin{array}{l}23.2 \\
17.6 \\
13.3\end{array}$ & 18.0 & 134 & $\begin{array}{c}60.6 \\
66.4 \\
-\end{array}$ & 63.5 \\
\hline 7 & Sulfate of ammonia & 18.0 & 18.0 & 134 & 69.2 & 69.2 \\
\hline 10 & Peat moss & 17.3 & 17.3 & 129 & 47.7 & 47.7 \\
\hline $1 \frac{2}{15}$ & $\begin{array}{l}\text { Milorganite } \\
\text { Milorganite }\end{array}$ & $\begin{array}{l}16.6 \\
11.2\end{array}$ & 13.9 & 104 & $\begin{array}{l}50.8 \\
36.3\end{array}$ & 43.6 \\
\hline $\begin{array}{r}1 \\
9 \\
14 \\
11 \\
5\end{array}$ & $\begin{array}{l}\text { Untreated } \\
\text { Untreated } \\
\text { Untreated } \\
\text { Untreated } \\
\text { Untreated }\end{array}$ & $\begin{array}{l}18.5 \\
14.7 \\
11.7 \\
11.4 \\
10.7\end{array}$ & 13.4 & 100 & $\begin{array}{l}52.2 \\
46.3 \\
33.9 \\
40.9 \\
32.5\end{array}$ & 41.2 \\
\hline & Mean, all treatments & & 16.7 & & & 52.5 \\
\hline
\end{tabular}


Where the fertilizer was applied either prior to or shortly after seeding, there was considerable yellowing of the needles, and in some cases, particularly in the use of concentrated soluble materials, there was definite injury. Growth response was slight and inconsistent. On the basis of dry weight per 10 plants, the mean of all treatments was $1.30 \mathrm{gm}$., as compared with $1.22 \mathrm{gm}$. for the untreated plots. Those reeeiving Hyperhumus showed up best with an average of $1.47 \mathrm{gm}$.

In another case, the untreated plots and those receiving Sorbex were superior to those receiving either fish, Milorganite, an organie mixture (5-6-1), or an 11-6-6 mixture.

Where fertilizer treatment was not made until the beginning of the second year, the response was more satisfactory, ranging up to 69 percent increase in dry weight for peat moss plus 20-8-8 over the average of the checks, as seen in Table 2. It will be noted that there is a fairly good correlation between needle length and dry weight of the plants. It appears that fish, peat moss, and the formulae 20-8-8 and 6-17-13 were beneficial, while Milorganite and 15-30-15 were of questionable value.

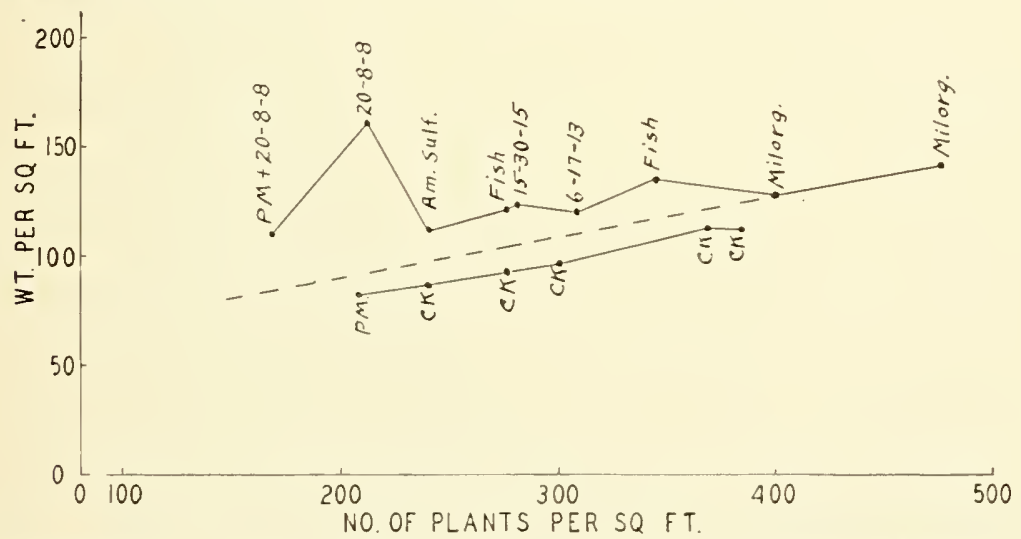

Figure 110. Relation between fertilizer treatment, number and weight of plants per square foot. Windsor seedbeds.

The treatments were repeated, and the following spring measurements were made which are recorded in Table 3 . When based on weight per 100 plants, all treatments except Milorganite produced larger plants than were obtained in the untreated plots. The 20-8-8 mixture alone and with peat moss was by far the best of the lot, producing a gain of 133 and 100 percent respectively. In agreement with the findings of other workers, the toproot ratio is higher in fertilized trees than it is in those untreated, which is, of course, a disadvantage in transplanting. The plant with a well-developed root system in proportion to top is in a better position to survive and make good growth than is one not so farored.

Interesting relationships between size of plant and density of the stand are shown in Figures 110 and 111 . The five checks and the peat moss treatment arrange themselves nicely below the theoretical average; the Milorganite is approximately in the average, while the other treatments are all above the average. 
Table 3. Effect of Fertilization on Red Pine Seedlings

Three Years from Seed When Dug

(Planted Spring 1932. Dug Apr. 5, 1935)

\begin{tabular}{|c|c|c|c|c|c|c|c|c|c|c|c|}
\hline \multirow{2}{*}{\multicolumn{2}{|c|}{$\begin{array}{l}\text { Plot } \\
\text { No. }\end{array}$}} & \multicolumn{3}{|c|}{ Dry weight 100 plants } & \multicolumn{2}{|c|}{$\begin{array}{c}\text { Top-root ratio } \\
(\mathrm{T} / \mathbf{R})\end{array}$} & \multicolumn{2}{|c|}{$\begin{array}{l}\text { No. of plants } \\
\text { per sq. ft. }\end{array}$} & \multicolumn{2}{|c|}{$\begin{array}{l}\text { Dry Weight } \\
\text { per sq. ft. }\end{array}$} & \multirow{2}{*}{$\begin{array}{c}\text { Stand } \\
\text { den- } \\
\text { sity }\end{array}$} \\
\hline & & g. & Av. & $\begin{array}{l}\text { Rela- } \\
\text { tive. }\end{array}$ & & Av. & & Av. & g. & Av. & \\
\hline \multirow{4}{*}{$\begin{array}{l}12 \\
6 \\
4 \\
8 \\
7\end{array}$} & $\begin{array}{c}\text { Peat Moss + } \\
20-8-8\end{array}$ & 65.4 & 65.4 & 200 & 5.31 & 5.31 & 168 & 168 & 110 & 110 & Good \\
\hline & $20-8-8$ & 75.8 & & & 6.43 & & 212 & & 161 & & Good \\
\hline & $\begin{array}{c}15-30-15 \\
6-17-13\end{array}$ & $\begin{array}{l}44.1 \\
38.8\end{array}$ & 52.9 & 163 & $\begin{array}{l}4.02 \\
3.91\end{array}$ & 4.79 & $\begin{array}{l}280 \\
308\end{array}$ & 267 & $\begin{array}{l}124 \\
120\end{array}$ & 135 & $\begin{array}{l}\text { Good } \\
\text { Good }\end{array}$ \\
\hline & $\begin{array}{l}\text { Sulfate of } \\
\text { ammonia }\end{array}$ & 46.6 & 46.6 & 143 & 4.75 & 4.75 & 240 & 240 & 112 & 112 & Good \\
\hline $\begin{array}{r}13 \\
3\end{array}$ & $\begin{array}{l}\text { Fish } \\
\text { Fish }\end{array}$ & $\begin{array}{l}44.2 \\
39.7\end{array}$ & 42.0 & 129 & $\begin{array}{l}4.13 \\
4.27\end{array}$ & 4.20 & $\begin{array}{l}276 \\
344\end{array}$ & 310 & $\begin{array}{l}122 \\
136\end{array}$ & 129 & $\begin{array}{l}\text { Good } \\
\text { V.good }\end{array}$ \\
\hline 10 & Peat Moss & 40.0 & 40.0 & 123 & 5.00 & 5.00 & 208 & 208 & 82 & 32 & Good \\
\hline 11 & Untreated & 36.4 & \multirow{5}{*}{32.5} & \multirow{5}{*}{100} & 2.77 & \multirow{5}{*}{3.90} & 240 & \multirow{5}{*}{313} & 87 & \multirow{5}{*}{100} & Fair \\
\hline 5 & Untreated & 33.6 & & & 4.02 & & 276 & & 93 & & Good \\
\hline 9 & Untreated & 32.3 & & & 4.62 & & 300 & & 97 & & Good \\
\hline 14 & Untreated & 30.8 & & & 4.13 & & 368 & & 113 & & Good \\
\hline 1 & Untreated & 29.3 & & & 3.94 & & 384 & & 112 & & Good \\
\hline \multirow{2}{*}{$\begin{array}{r}15 \\
2\end{array}$} & Milorganite & 32.0 & 30.8 & \multirow[t]{2}{*}{95} & 3.33 & 3.58 & 400 & 438 & 128 & 135 & Good \\
\hline & Mean & & 41.2 & & & 4.38 & & 299 & & 115.8 & \\
\hline
\end{tabular}

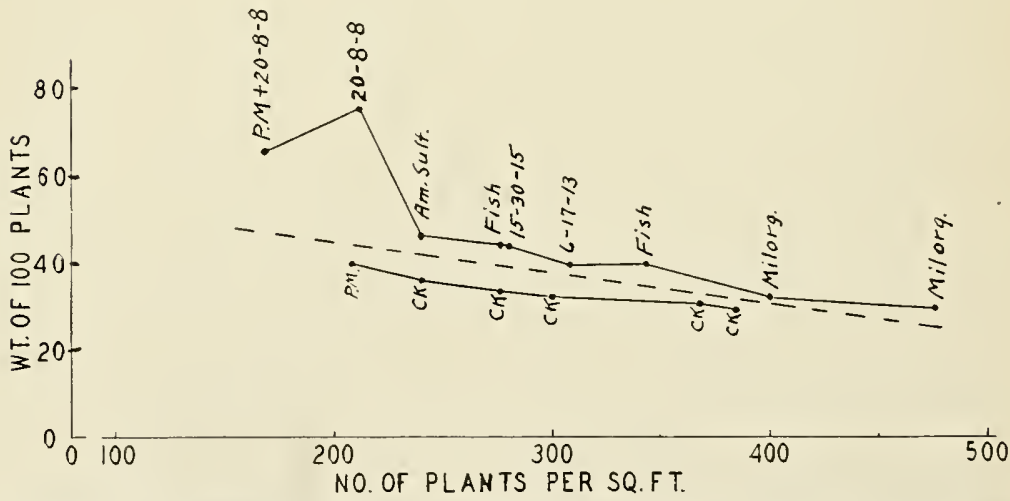

Figure 111. Relation between fertilizer treatment, number of plants per square foot and weight of 100 plants. Windsor seedbeds. 


\section{Seedbed Fertilization at the Peoples Forest Nursery}

In the spring of 1935 experimental work was started in a limited way on the Peoples Forest Nursery at Barkhamsted. The nursery is situated on Merrimac loamy sand. Seedling beds of one-year-old plants (seed sown spring, 1934) of red pine, white pine ( $P$. strobus), larch (Larix decidua), Norway spruce (Picea Abies), and white spruce $(P$. glauca) were selected and each species received the following treatments:

\begin{tabular}{|c|c|c|c|}
\hline ot 1 & Fish & 300 lbs. per A. & $(2 \mathrm{lbs} . \mathrm{N} / \mathrm{A})$ \\
\hline 3 & $12-16-12$ & 600 “" & $\left(\begin{array}{lll}54 & \\
(12 & & \\
(\end{array}\right.$ \\
\hline & & $200 ،$ & $(24$ " \\
\hline
\end{tabular}

The materials were applied dry on May 8 and brushed off the trees with a broom.

On July 31 it was observed that white pine trees treated with 200 pounds of 12-16-12 appeared slightly greener than the untreated trees, and on white spruce the light, complete fertilizer treatment seemed slightly superior. Norway spruce appeared to be somewhat better on the portions of the bed receiving either amount of 12-16-12 than it did on either fishtreated or the no-treatment portions of the bed. Otherwise, no differences were noted.

Early in April, 1936, it was observed that the Norway spruce trees which had received 600 pounds of fish were somewhat superior to those growing under other treatments. On the other hand, white spruce with 12-16-12 fertilizer was slightly better than with either fish or no treatments.

In no case were the results at all striking, and no definite conclusions could be drawn from the work. It is quite probable that the date of application, May 8 , while seemingly early enough, was still too late to be of use to the current season's growth. This is especially true in the case of fish meal which becomes available slowly. The work at this nursery was conducted more for demonstrational purposes than for scientific accuracy, and for this reason no actual measurements of the trees were made. It was felt that if the effect of treatment was not great enough to be detected by ocular observation, it was not significant.

In the following spring fertilizers were applied (April 15, 1936), to three species of 1-0 stock (seed planted 1935) as follows, using areas 4 by 10.9 feet $(1 / 1000$ A.) for each treatment:

\begin{tabular}{|c|c|c|c|}
\hline Norway spruce & $\begin{array}{l}7-6-6 \\
\text { Fish }\end{array}$ & $\begin{array}{l}400,800,1200 \mathrm{lbs} . / \mathrm{A} \\
500,1000,1500 \mathrm{lbs} . / \mathrm{A} \\
500,1000,2000 \mathrm{lbs} . / \mathrm{A}\end{array}$ & $\begin{array}{l}\text { in duplicate } \\
\text { singles }\end{array}$ \\
\hline White spruce & $\begin{array}{l}\text { 7-6-6 } \\
\text { Fish }\end{array}$ & $\begin{array}{l}400,800,1200 \mathrm{lbs} . / \mathrm{A} \\
500,1000,1500 \mathrm{lbs} . / \mathrm{A}\end{array}$ & singles \\
\hline
\end{tabular}

On July 23 it was observed that growth on one set of treatments on Norway spruce appeared slightly inferior to the untreated portion. No differences could be noted on any other beds. On October 27 there were 
no differences apparent except in the case of Norway spruce where the fish treatment seemed to cause slightly poorer growth, and the 7-6-6 fertilizer slightly better growth, than the untreated portions.

\section{Conclusions on Seedbed Studies}

From the foregoing presentation the following conclusions may be drawn, applicable to the conditions of the experiments:

1. In general, the use of fertilizers and soil amendments has been beneficial to red pine seedlings to a greater or lesser degree.

2. There has been an inconsistency in the response of these seedlings to different kinds of fertilizer-sometimes one, sometimes another giving best results. However, there was a tendency for the organic fertilizers to be superior to inorganic types. Of the complete fertilizers used, the one high in nitrogen (20-8-8) seemed to give best results.

3. It is very easy to over-fertilize seedlings, particularly with concentrated, soluble materials. In the light of the experiences of Mitchell (9) and others in seedbed work, it is quite probable that more satisfactory results can be obtained from the use of fertilizer if it is applied in frequent, light doses in soluble form. The seedlings grow so slowly that excess soluble fertilizer is either leached out before it is absorbed, or, if too concentrated, it injures the seedlings.

\section{TRANSPLANT BED STUDIES}

\section{Experiments at Windsor}

\section{First Experiment, Main Series}

Commencing in the spring of 1930 a series of experiments were started to determine the response of conifers, especially red pine, to fertilization in the transplant bed. Sixty plots 4 by 8 feet were laid out at Windsor on Merrimac loamy sand, 42 of which constituted the main series of 14 treatments in triplicate, while the remaining 18 plots were used for extra treatments of one kind or another. The amount of nitrogenous fertilizer was based on 100 pounds of nitrogen per acre. The materials used in the main series and the rate of application, in pounds per acre, were:

$\begin{array}{lrlr}\text { Ammonium sulfate } & 475 & \text { Manure (cow) } & 20,000 \text { (wet) } \\ \text { Calnitro } & 500 & \text { Potassium sulfate } & 210 \\ \text { Castor pomace } & 2,000 & \text { Sodium nitrate } & 666 \\ \text { Cottonseed meal } & 1,500 & \text { Superphosphate }(16 \%) & 50 \\ \text { Fish meal } & 1,165 & \text { Urea } & 220 \\ \text { Limestone } & 4,000 & 6-8-7 & 1,325\end{array}$

The organic materials, including the 6-8-7 mixture, were applied prior to planting and worked into the soil with a hoe. All other fertilizers were applied as a top dressing, using the dry salts mixed with sand to aid in obtaining uniform distribution. Red pine seedlings, two years from seed, were planted May 5, 6 and 7, 30 trees to the row and 15 rows to the full size plot. 
Soil samples from all plots, representing some 16 treatments, were collected on four separate dates during the summer and tested for acidity, ammonia nitrogen and nitrate nitrogen. The findings are given graphically in Figure 112. It is to be noted that some of the treatments had a very distinct effect upon soil reaction. Both treatments containing urea and all organics except tankage caused an increase in acidity. The extreme acidity resulting from the high applications of Nitrophoska can be ascribed to the high nitrate content. The ammonia nitrogen data for the first three periods were not very reliable and should not be taken too seriously. The data on nitrates are dependable and they show quite striking differences with respect to both date of sampling and treatment.

\section{Results of Treatment on Growth of Plants, Main Series}

The main series will be discussed first before considering the single plots.

Because the planting stock was used as it came from the beds without selection, the trees in this experiment varied greatly in size. At the time of measurement in April, 1931, it was necessary to recognize three size classes: small, medium and large. Five typical trees of each size-class were removed from each plot. The 1930 growth of leader and the needle length were measured, and the green weights of the whole plant and dry weights of both tops and roots were obtained. In order to make fair comparison between plots, the number of rows or fractions of a row of each size class was estimated and these values were used in calculating the weighed totals. This latter value is the sum of the products of the measurement in question and the number of plants of each plant size. For example, the data for the green weight of the plants in plot 1 are as follows:

\begin{tabular}{|c|c|c|c|}
\hline 1 & 2 & 3 & 4 \\
\hline Class & $\begin{array}{l}\text { Average } \\
\text { green weight } \\
\text { per plant }\end{array}$ & No. of rows & $\begin{array}{l}\text { Weighed value } \\
\qquad(2 \times 3)\end{array}$ \\
\hline Small & 1.7 & 2.0 & 3.1 \\
\hline Medium & 9.1 & 11.0 & 103.1 \\
\hline \multirow[t]{2}{*}{ Large } & 24.2 & 1.0 & 24.2 \\
\hline & & Weighed total & 131.0 \\
\hline
\end{tabular}

The data so calculated are found in Table 4. It must be borne in mind that these data are only of limited value because of the original variation between plots. Under the conditions of the experiment it appears that the soluble materials were most effeetive in influencing growth. Eight of the 14 treatments showed a positive response, while 5 were negative. That soluble fertilizers stimulate top growth rather than root development is shown by the ratio of tops to roots. Shoot growth was well correlated with dry weight, but little can be said for needle length in this respect.

Shoot growth and needle length were compared statistically and found to have a correlation of $.702 \pm .024$, based on 198 measurements. 

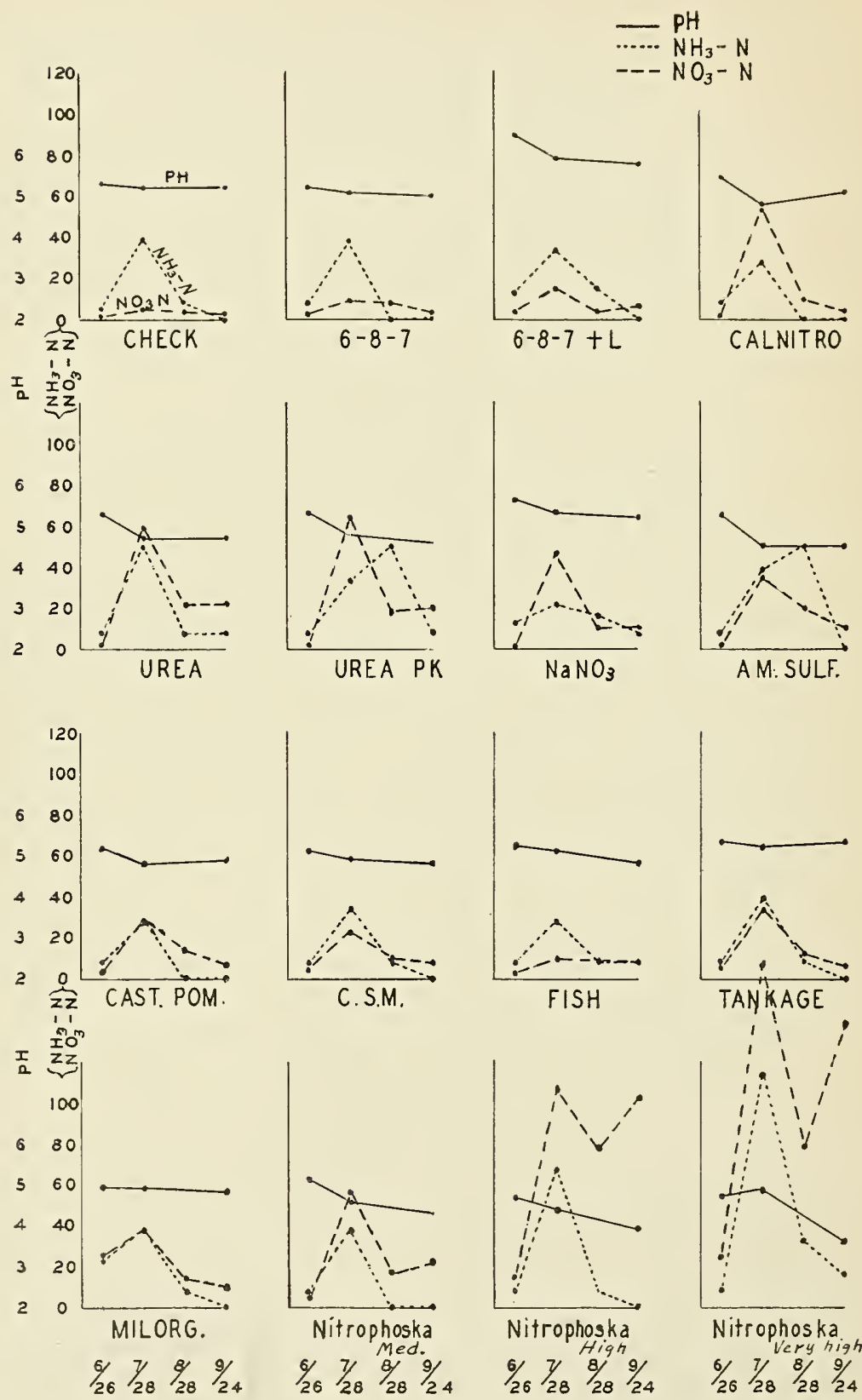

Figure 112. Soil tests, Windsor transplant beds. 1930. 
Table 4. Results of Fertilization of Red Pine Transplants

Windsor, Main Series, Season of 1930

Arranged in order of decreasing weight of whole plant

Weighted totals (except needle length)

\begin{tabular}{|c|c|c|c|c|c|c|}
\hline \multirow[b]{2}{*}{ Treatment } & \multirow{2}{*}{$\begin{array}{l}\text { No. of } \\
\text { plots }\end{array}$} & \multicolumn{2}{|c|}{ Total dry weight } & \multirow{2}{*}{$\frac{\text { Tops }}{\text { Roots }}$} & \multirow{2}{*}{$\begin{array}{l}\text { Shoot } \\
\text { growth } \\
\text { cm. }\end{array}$} & \multirow{2}{*}{$\begin{array}{l}\text { Needle } \\
\text { length } \\
\text { cm. }\end{array}$} \\
\hline & & g. & Relative & & & \\
\hline Sodium Nitrate $+\mathrm{K}$ & 3 & 252.7 & 166 & 3.99 & 75.5 & 7.52 \\
\hline Ammonium Sulfate $+K$ & 2 & 239.1 & 157 & 4. 70 & 67.2 & 8.59 \\
\hline Calnitro + K & 3 & 213.1 & 140 & 3.57 & 68.4 & 8.27 \\
\hline $\mathrm{K}$ & 3 & 208.7 & 137 & 3.95 & 73.3 & 8.29 \\
\hline Urea + K & 3 & 171.3 & 113 & 3.31 & 60.6 & 7.98 \\
\hline Urea + PK & 5 & 162.1 & 106 & 3.13 & 58.9 & 8.39 \\
\hline Urea & 3 & 160.4 & 105 & 3.46 & 61.1 & 8.18 \\
\hline Manure & 2 & 158.2 & 104 & 3.30 & 58.3 & 8.53 \\
\hline Untreated & 8 & 152.4 & 100 & 3.36 & 57.5 & 8.19 \\
\hline $6-8-7+$ lime & 2 & 132.0 & 87 & 3.53 & 12.8 & $\div .53$ \\
\hline Castor pomace $+K$ & 3 & 126.6 & 83 & 2.91 & 58.2 & 6.95 \\
\hline $6-8-7$ & 7 & 119.0 & 79 & 3.62 & 50.3 & 8.30 \\
\hline Fish $+\mathrm{K}$ & 3 & 116.1 & 77 & 3.13 & 52.4 & 8.45 \\
\hline $\begin{array}{c}\text { Cottonseed meal }+\mathbf{K} \\
\text { Mean }\end{array}$ & $\begin{array}{r}3 \\
50\end{array}$ & $\begin{array}{l}102.7 \\
174.8\end{array}$ & 68 & 3.02 & 49.3 & 8.57 \\
\hline
\end{tabular}

*Obtained by averaging all plots; not simply an average of the figures given above.

Table 5. Measurement of 1931 Growth, Red Pine Transplants

Windsor, Main Series. (Planted 1931)

(Average of 3 plots for each treatment)

\begin{tabular}{|c|c|c|}
\hline Treatments & $\mathrm{cm}$. & Relative \\
\hline Fish & 8.1 & 111 \\
\hline Muriate of potash & 7.9 & 108 \\
\hline Nitrate of sorla & 7.8 & $10 \%$ \\
\hline Castor ponace & 7.8 & 107 \\
\hline Cottonseed meal & 7.7 & 105 \\
\hline $16-15-17$ & $\div 7$ & 105 \\
\hline Manure & $\div \div$ & 105 \\
\hline Urea + K & 7.7 & 105 \\
\hline Sulfate of ammonia & 7.7 & $10 \tilde{5}$ \\
\hline Urea & $\div .6$ & 104 \\
\hline $16-15-17+\mathrm{L}$ & 7.6 & 101 \\
\hline Urea PK & 7.6 & 101 \\
\hline Check & 7.3 & 100 \\
\hline Calnitro & $\div .3$ & 100 \\
\hline
\end{tabular}

Second Windsor Experiment with Transplants, Main Series

All plants in the main series (beds 1-42) were removed. The beds were spaded and fertilized as in the original application in 1930 , except that in place of the 6-8-7 mixture, a new "forest formula" 16-15-17*, was used at

* 16-15-17: Potassium nitrate 16 parts, potassium chloride 20, sodium nitrate 16, Ammophos "A" 32 , urea 16. 
the rate of 75 pounds of nitrogen per aere. Two-year-old red pine seedlings which had been hand-seleeted to insure uniformity were earefully planted May 11-18, all by one man. In the fall 10 average trees were measured to determine the amount of growth put on in the current year. As we see in Table 5, the differenees were small, the average heights ranging from $7.27 \mathrm{~cm}$. to $8.10 \mathrm{~cm}$., or an inerease of 11 percent.

For the next year, 1932, treatments were repeated on the basis of 75 pounds of nitrogen per acre for the organies, and 100 pounds for the soluble fertilizers, the latter in two applieations. $\mathrm{KCl}$ was used in place of $\mathrm{K}_{2} \mathrm{SO}_{4}$, and a 20-8-8 mixture was substituted for the 16-15-17. In late September the total height was taken of all trees in every other row of every plot. Later, 25 average trees were eut out and dry weights obtained.

The data, contained in Table 6, show that, based on height of plants, the organie fertilizers were superior to the inorganics; but the dry weight figures show a somewhat different pieture, some of the soluble materials being equal or superior to the organics. In all eases, however, the treated plots produced larger trees than the untreated.

In April, 1933, all trees were removed; but before this was done 35 average trees from the triplicate plots of 8 different treatments were saved for planting out. The trees were selected by measurement based on the previous fall's results. The land was re-worked, fertilized as in previous years, and planted to oats and later to buekwheat. The yields of both crops were elosely correlated with $\mathrm{pH}$ of the soil, the sodium nitrate and the limed plots being the best, and the sulfate of ammonia plots the poorest.

Table 6. Height and Dry Weight of Red Pine Transplants, Fall, 1932 Windsor, Main Series. (Planted 1931)

(Average of 3 plots for each treatment)

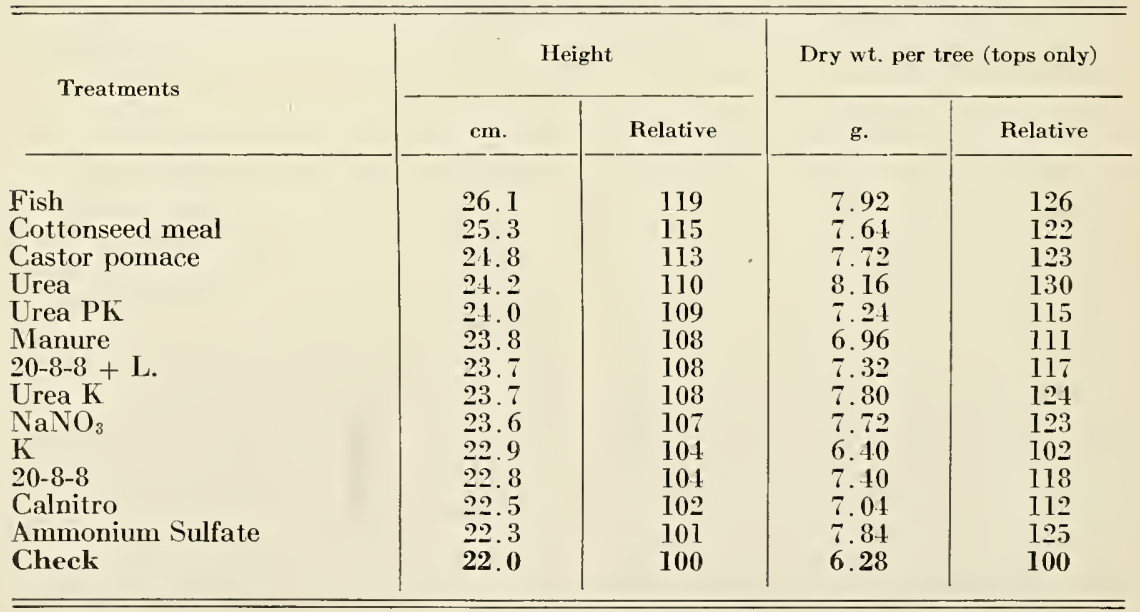




\section{Results with Other Materials on the Single Plots}

As stated on page 732 , of the 60 plots laid out and planted in 1930, 18 were single plots used for trying out a variety of materials which could not be included in the main series. These materials and their rates of application were:

\begin{tabular}{lclr} 
Bloodmeal & 1,000 & Peat Moss & 19,060 (air dry) \\
Hyperhumus & 32,670 & Red pine duff & 14,720 \\
Magnesium sulfate & 300 & Sulfur & 200 \\
Milorganite & $2,22+4$ & Tankage, bone & 3,000 \\
\multicolumn{2}{r}{ Nitrophoska $(15-30-15)$} & $666,1,333,2,666$ &
\end{tabular}

At the end of the first season, only one treatment, 666 pounds of Nitrophoska, gave results definitely superior to those on the untreated plots. The gain was 30 percent. The two poorest treatments were red pine duff, 52 percent below the checks, and the high application of Nitrophoska, 63 percent below. It will be recalled that the latter resulted in a very high degree of acidity in the soil.

These trees were not removed at the end of the first season but were carried through until the fall of 1931. with the treatments essentially the same as in 1930 except Nitrophoska which was not repeated. Final measurement in the fall did not reveal any striking results one way or another. It was noted, however, that plots which received a complete fertilizer the current year were somewhat superior to those treated only in the preceding year.

In the refertilization of the plots on April 18, 1932, sulfur, magnesium sulfate and red pine duff were dropped, and Hyperhumus or Milorganite used in their stead. Only the lorest application of Nitrophoska was used. The plots were then planted with hand-selected, I wo-year pine seedlings. Measurements made in the fall of 1932 and again a year later revealed considerable inconsistency in the growth response to the various treatments. The maximum increase was 46 percent, but in many cases the gain was slight. Yields of an oat erop which followed the removal of the pines showed very little correlation with the growth of the latter.

\section{Summary of the work on the Windsor transplant beds}

The foregoing presentation of the results obtained in the transplant beds at Windsor indicates a general response to fertilizers, ranging up to 46 percent better than the untreated plots. Frequently, differences due to treatment were hardly noticeable in the field and could be ascertained only upon actual measurement. There was much inconsistency in response to different kinds of fertilizer and the results obtained do not warrant any positive conclusions on the matter.

\section{Transplant Bed Experiment at Rainbow}

In order to obtain additional data on the response of red pines to fertilization, a transplant bed was established on coarse sand at the Rainbow 
plantation. In April, 1933, a fairly open area was cleared of a few gray birch and young spruce and pine, and then plowed and harrowed. On April 28 it was laid off into 48 plots, each 4 by 5.5 feet, and fertilized as follows:

Plot Nos.

$1-16-32-47$

2-17.33-48

$3-18 \cdot 31-37$

4-19-35-38

$5-20-36-39$

$6-21-25-40$

$7-22-26-41$

$8-23-27-42$

9-21-28-43

$10-13-29-44$

$11-14-30-45$

12-15-31-46
Treatment

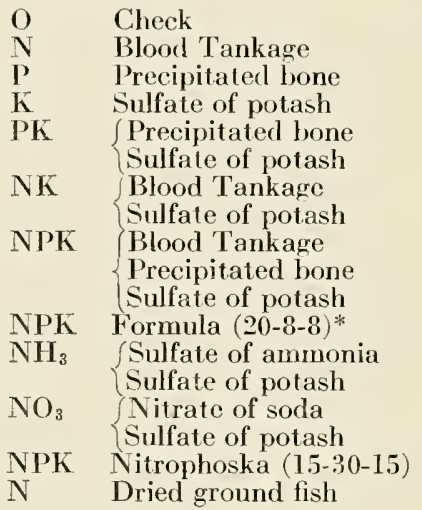

O Check

P Precipitated bone

$\mathrm{K} \quad$ Sulfate of potash

Precipitated bone

ilfate of potash

Sulfate of potash

ood lankage

Precipitated bone

Formula (20-8-8)*

Sulfate of potash

Nitrate of soda

Nitrophoska (15-30-15)

*For composition of 20-8-8, see p. 726

$\begin{array}{ccc}\begin{array}{c}\text { Amount Fertilizer } \\ \text { per plot } \\ \text { g. }\end{array} & \begin{array}{c}\text { Amount } \\ \text { tbs. }\end{array} & \begin{array}{c}\text { Amper A } \\ \text { fbs. }\end{array} \\ \ldots 30 & 1005 & 75 \\ 83 & 363 & \ldots \\ 18 & 210 & \ldots \\ 83 & 363 & \ldots \\ 48 & 210 & \ldots \\ 230 & 1005 & 75 \\ 48 & 210 & \ldots \\ 230 & 1005 & 75 \\ 83 & 363 & \ldots \\ 48 & 210 & \ldots \\ 57 & 249 & 50 \\ 54 & 236 & 50 \\ 48 & 210 & \ldots \\ 72 & 315 & 50 \\ 48 & 210 & \ldots \\ 76 & 332 & 50 \\ 203 & 887 & 75\end{array}$

Early in May 1t,400 hand selected, two-year red pine seedlings were planted, 30 trees per row and 10 rows per plot. Incidentally, the 24,540 trees (nursery-run stock), taken from the nursery, graded out as follows:

Selected trees 60.4 percent; large discards 4.6; small discards 35.0.

It is believed that these figures represent better than average nursery bed run, for the section used was chosen for its uniformity.

Because of injury from some of the treatments, notably ammonium sulfate and sodium nitrate, the amount of fertilizer applied in 1934 was only half that of the original application. Thus, the amount used was equivalent to 25 pounds of $\mathrm{N}$ in the inorganic fertilizers, and 37.5 pounds in the tankage and fish treatments. In 1935 the amount was increased to two-thirds of the original, or 33.3 pounds of inorganic $\mathrm{N}$ and 50 pounds of organic N. In order to prevent over-crowding during the last year, every other tree was cut out in November, 1934, and the trees removed from each plot were dried and weighed. Measurements taken in October 1935 concluded the work on this particular transplant bed, and the plants were removed the following spring.

\section{Results}

The first season there was very little difference in height of the trees on the various plots, but there was a marked difference in stand, the nitrate of soda and the sulfate of ammonia plots showing definite injury.

The results for the second season are given in Table 7 , in which the treatments are arranged in order of decreasing total dry weight per plot. Here we find the organics alone and phosphorus alone superior to the checks, with a gradual decrease to the ammonium sulfate plots which were 
Table 7. Effect of Fertilization on Red Pine Growth Rainbow, 2nd Season, 1934. (Planted 1933)

(Order based on total dry weight per plot)

\begin{tabular}{|c|c|c|c|c|c|c|c|c|}
\hline \multirow{2}{*}{$\begin{array}{l}\text { Plot } \\
\text { No. }\end{array}$} & \multirow{2}{*}{ Treatment } & \multicolumn{2}{|c|}{$\begin{array}{c}\text { Total dry wt. } \\
\text { per plot }\end{array}$} & \multicolumn{2}{|c|}{$\begin{array}{l}\text { Dry weight per } \\
100 \text { trees }\end{array}$} & \multirow{2}{*}{$\begin{array}{c}\text { Av. } \\
\text { height } \\
\text { cm. }\end{array}$} & \multirow{2}{*}{$\begin{array}{l}\text { Growth } \\
\text { in } 1934 \\
\text { \& of all } \\
\text { plants in } \\
\text { each plot }\end{array}$} & \multirow{2}{*}{$\begin{array}{l}\text { Needle } \\
\text { length } \\
\text { mm. }\end{array}$} \\
\hline & & g. & Relative & g. & Relative & & & \\
\hline 2 & Tankage & 797 & 117 & 634 & 1I. 1 & 21.0 & 2960 & 90.3 \\
\hline 12 & Fish & 760 & 112 & 572 & 103 & 23.8 & 3092 & 92.0 \\
\hline 3 & $\mathrm{P}$ & 727 & 107 & $5 \div 6$ & 103 & 22 . & 2438 & 95.5 \\
\hline 8 & $20-8-8$ & 687 & 101 & 619 & 111 & 23.2 & 2641 & 97.4 \\
\hline 1 & Check & 681 & 100 & 558 & 100 & 22.4 & 2749 & 97.9 \\
\hline 5 & $\mathrm{PK}$ & 655 & 96 & 527 & 94 & 22.2 & 2171 & 108.1 \\
\hline 6 & Tank. + K & 649 & 95 & 601 & 108 & 22.3 & 2119 & 113.7 \\
\hline 11 & Nitrophoska & 610 & 90 & 571 & 102 & 22.1 & 2539 & 1056 \\
\hline 7 & Tank. PK & 592 & 87 & 581 & $10-1$ & 21. & 193 & 108. 2 \\
\hline 4 & $\mathrm{~K}$ & 570 & 31. & 492 & 88 & 20.7 & 19.18 & 101.7 \\
\hline 10 & $\mathrm{NaNO}_{3}+\mathrm{K}$ & 519 & 76 & 515 & 98 & 20.9 & 1485 & $10 \% .1$ \\
\hline 9 & Am. Sulf. $+\mathrm{K}$ & 371 & 55 & 582 & 101 & 20.2 & 1463 & 120.9 \\
\hline & Mean & 635 & & 572 & & 22.2 & 2320 & 103.4 \\
\hline & 9 and 10$)$ & 673 & & & & & 2189 & \\
\hline
\end{tabular}

distinctly poorer. Dry weight per 100 trees shows little correlation with the weight for the whole plot. On the other hand, average height per tree shows remarkably good correlation with total dry weight, although, in agreement with Némec's results (15), height varies much less than weight.

Both the sum of the heights and the total sum of the growth are well correlated with tolal dry weight. It should be noted that in every case except one the check plots were superior to the mean, even when the obviously injured plots 9 and 10 are omitted from the mean. Needle length is inversely related to height and growth.

Results for the 1935 season are found in Table 8. It is interesting to note that the check plots dropped to tenth place relative to the sum of

Table 8. Effect of Fertilization on Red Pine Growth Rainbow, 3rd Season, 1935. (Planted 1933)

(Order based on $=$ of heights)

\begin{tabular}{|c|c|c|c|c|c|c|c|}
\hline \multirow[t]{2}{*}{ No. } & \multirow[t]{2}{*}{ Treatment } & \multicolumn{2}{|c|}{$\begin{array}{c}\text { heights. Av. for } \\
\text { each plot }\end{array}$} & \multirow{2}{*}{$\frac{\begin{array}{c}\text { growth } \\
\text { in } 1935\end{array}}{\mathrm{~cm} .}$} & \multirow{2}{*}{$\begin{array}{c}\begin{array}{c}\text { Av. } \\
\text { height } \\
\text { each plant }\end{array} \\
\mathrm{cm} .\end{array}$} & \multicolumn{2}{|c|}{$\begin{array}{l}\text { Av. growth per tree } \\
\text { in } 1935\end{array}$} \\
\hline & & $\mathrm{cm}$. & Relative & & & $\mathrm{cm}$. & Relative \\
\hline 5 & $\mathrm{PK}$ & 2529 & 113 & 1322 & 35.5 & 13.3 & 130 \\
\hline 8 & $20-8-8$ & 2522 & 113 & 4155 & 34.8 & 11.6 & 114 \\
\hline 2 & Tankage & 2488 & 111 & $35 \div 2$ & 36.8 & 12.8 & 126 \\
\hline 12 & Fish & 2.167 & 111 & 3243 & 34.9 & 11.1 & 109 \\
\hline 3 & $\mathrm{P}$ & 2384 & 107 & 3425 & 33.8 & 10.9 & 107 \\
\hline 6 & Tank + K & 2305 & 103 & 3859 & 36.1 & 13.8 & 135 \\
\hline 7 & Tank + PK & 2284 & 102 & $\$ 168$ & 35.8 & 14.0 & 137 \\
\hline 4 & $\mathrm{~K}$ & 2211 & 101 & 3664 & 32.5 & 12.0 & 118 \\
\hline 11 & Nitrophoska & 2213 & 101 & $334 \%$ & 33.6 & 11.5 & 113 \\
\hline 1 & Check & 2234 & 100 & 2808 & 32.6 & 10.2 & 100 \\
\hline 10 & $\mathrm{NaNO}_{3}$ & 1780 & 80 & 3018 & 32.5 & 11.6 & 114 \\
\hline 9 & Am. Sulf. & 1639 & 73 & 2911 & 32.6 & 12.4 & 122 \\
\hline & Mean & 2260 & & 3541 & 34.3 & 12.1 & \\
\hline
\end{tabular}


heights, and to the twelfth place from the standpoint of 1935 growth. The 20-8-8 treatment advanced from seventh place in 1933, to fourth in 1934, and second in 1935. The correlation between height of the individual tree and the sum of the height measurements is good, indicating that tree size as well as stand density is influenced by the treatment. Soil tests, made from time to time, revealed no definite correlation with growth of the plants, although the effect of treatment was generally registered in the tests. The data in Table 9 are typical.

Table 9. Soll Tests by the Universal Rapid Method Rainbow Transplant Bed-Oct. 10, 1934

(Pounds per Acre)

\begin{tabular}{|c|c|c|c|c|c|c|c|}
\hline Treatment & Plot No. & $\mathrm{pH} *$ & $\mathrm{NH}_{3}-\mathrm{N}$ & $\mathrm{NO}_{3}-\mathrm{N}$ & $\mathbf{P}$ & K & $\mathrm{Al}$ \\
\hline Check & 1 & 4.65 & 7.5 & 3 & 20 & 125 & 400 \\
\hline Tankage & 2 & 4.90 & 10.0 & 4 & 25 & 150 & 400 \\
\hline & 3 & 5.10 & 10.0 & 5 & 125 & 150 & 350 \\
\hline K & 4 & 4.80 & 7.5 & 5 & 15 & 150 & 400 \\
\hline & 5 & 5.10 & 7.5 & $<2$ & 175 & 150 & 85 \\
\hline Tankage + K & 6 & 5.15 & 7.5 & $<2$ & 30 & 175 & 100 \\
\hline Tankage + PK & 7 & 4.80 & 6.0 & $<2$ & 75 & 150 & 200 \\
\hline $20-8-8$ & 8 & 4.70 & 6.0 & 2 & 40 & 125 & 250 \\
\hline Am. Sulf. + K & 9 & 4.65 & 7.5 & 2 & 20 & 150 & 300 \\
\hline $\mathrm{NaNO}_{3}+\mathrm{K}$ & 10 & 4.70 & 10.0 & 2 & 25 & 175 & 150 \\
\hline Nitrophoska & 11 & 4.60 & 8.0 & 2 & 40 & 175 & 200 \\
\hline Fish & 12 & 4.80 & 7.5 & $<2$ & 35 & 150 & 175 \\
\hline
\end{tabular}

*Determined electrometrically.

Of special interest is the amount of nitrate accumulation obtained when soil from some of the treatments was incubated 26 days. This is shown in Table 10. All of the treatments tested caused an increase in nitrification

Table 10. Effect of Soll Treatuient Upon Nitrification During A 26-Day Period of Incubation

Rainbow Transplant Bed-July, 1934

\begin{tabular}{|c|c|c|c|c|}
\hline \multirow{2}{*}{ Plot } & \multirow{2}{*}{ Treatment } & \multicolumn{3}{|c|}{$\mathrm{NO}_{3}-\mathrm{N}$ in ppm. } \\
\hline & & Initial & Final & Gain \\
\hline 1 & Check & 0.8 & 3.0 & 2.2 \\
\hline 2 & Tankage & 0.8 & 4.3 & 3.5 \\
\hline 8 & $20-8-8$ & 1.5 & 6.0 & 4.5 \\
\hline 9 & Am. Sulf. $+K$ & 1.7 & 10.3 & 8.6 \\
\hline 10 & $\mathrm{NaNO}_{3}+\mathrm{K}$ & 1.0 & 6.4 & 5.4 \\
\hline 11 & Nitrophoska & 1.0 & 13.1 & 14.1 \\
\hline 12 & Fish & 1.0 & 18.8 & 17.8 \\
\hline
\end{tabular}

greater than that in the untreated soil. Of particular significance is the low and relatively uniform nitrate content present on the date of sampling, indicating the active absorption of nitrates by the plant roots. A significant accumulation in the soil occurs only when root competition is eliminated. 
In this experiment the average length of needles, collected from the mid-point of the current season's leader, was correlated with growth as follows:

\section{Coefficient of correlation ( $\mathrm{r}$ ) between}

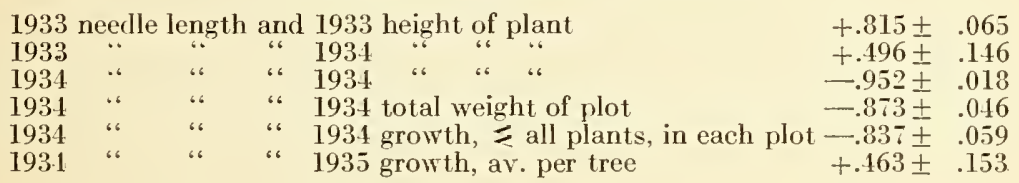

Thus we see that there is a good relationship between needle length and height, weight, or growth of plant in the same year, although it is direct in 1933, the first year, and inverse in 1934. The existence of an inverse relationship during the same year would suggest a direct relationship between needle length one year and growth the next year. However, the data on hand do not bear that out. In order to make adequate comparisons with grow th, it is necessary to take into consideration the number of needles as well as the length. Since the number was not determined, it is not possible to explain the apparent discrepancies in the foregoing correlations.

Early in June, 1935, there appeared a definite yellowing of one-half to three-fourths of the needle length of the needles on about 10 plots, including all plots receiving sulfate of ammonia. Apparently this condition was associated with inadequate soil moisture, for it disappeared a few weeks later, following about two inches of rain.

Summarizing the results of this particular work, it may be said that on this soil the response of red pine transplant stock to fertilization was not significant until the third season. Of the various materials compared, the organics-both tankage and fish-when used alone, were found near the top of the list in every case. The 20-8-8 mixture also made a fairly good showing. There was a relationship between needle length and growth during the current season. All treatments caused an increase in nitrification upon incubation of the soil.

\section{Experiments at Peoples Forest Nursery}

On May 8, 1935, fertilizers were applied as top dressings to 2-0 stock which had been put in the transplant bed the preceding month. The species and the treatments given were as follows: Red pine, white pine, Scotch pine, Norway spruce, white spruce, Douglas fir, and hemlock.

Treatments:

\begin{tabular}{|c|c|}
\hline a Fish & $400 \mathrm{lbs} . / \mathrm{A}$. \\
\hline & 800 \\
\hline c $12-16-12$ & 150 \\
\hline
\end{tabular}

Observations made July 31 indicate that all species except red pine, hemlock and Douglas fir showed some benefits from fish applications, especially in the heavier amounts. 
In the spring of 1936 a somewhat more extensive experiment was carried out as follows:

Transplant beds, planted with 2-0 stock, spring, 1936.

a. Applied before planting

Norway spruce $7-6-6$

Fish

$500,1000,1500 \mathrm{lbs} . / \mathrm{A}$.

$800,1600,2400$ "“"

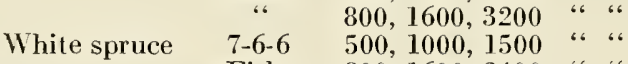

Fish $800,1600,2400$ " “

b. Applied as top dressing after planting

$\begin{array}{lllll}\text { White pine } & 7-6-6 & 400,800,1200 & \text { “ “ } \\ \text { Norway spruce } & \text { Fish } & 500,1000,2000 & \text { “ } 6 \\ & \text { Fish } & 400,800,1200 & \text { “ } & \text { “ } \\ & \text { Fish } 1000,2000 & \text { “ }\end{array}$

All treatments were applied between April 7 and 16.

No actual measurements of the trees were made for the reason that if the effect of treatment was not apparent to the eye, it was deemed not significant. This does not mean, however, that no increase took place. Further reason for not taking measurements was the fact that the trees were not selected and hence were for the most part quite irregular in size. On July 23, the treated white pine trees were greener and slightly larger than were the untreated trees. No other differences could be detected. Thus, the work of two seasons at this nursery yielded us little in the way of positive results from the use of fertilizers. The amounts used covered a range wide enough easily to come within the requirements of trees. It is interesting to observe that as much as 3,200 pounds of fish to the acre, equivalent to about 288 pounds of $\mathrm{N}$, was not injurious.

\section{SOIL FRAME STUDIES}

\section{Windsor Frames}

Ten concrete soil frames, each measuring 32 inches by 10 feet or 26.66 square feet, were filled with Enfield v.f.s.l. which rested on the natural subsoil of the Merrimac series below 20-inch depth. The initial soil treatment was as follows:

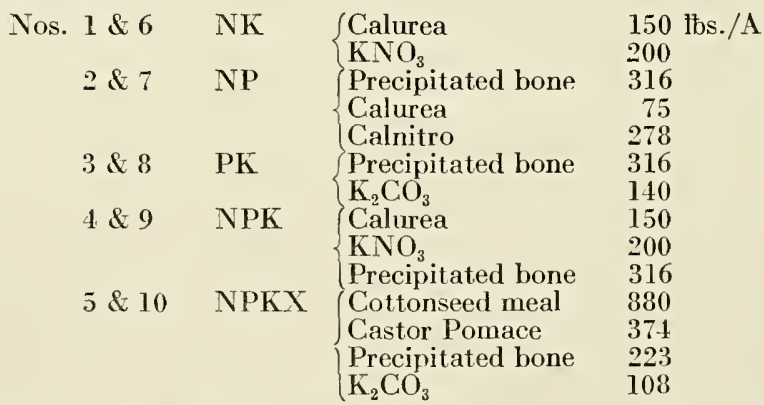

These amounts provided approximately 80 pounds of $\mathrm{N}, 120$ of $\mathrm{P}_{2} \mathrm{O}_{5}$ and 90 of $\mathrm{K}_{2} \mathrm{O}$ per acre. A crop of tobacco was grown in 1931 and then, in the middle of April, 1932, 72 hand-selected red pine seedlings, 2-0 stock, were planted in each frame. In the fall, the total height of each tree was measured, and two fasicles (pairs) of needles were collected from the midpoint on each stem. Treatment in 1933 was identical to that of the preceding year. 
In 1934 every other tree was cut out and weighed. Five trees from each plot were pulled out in order to get some idea of the root system. Because of this reduction in number of trees, fertilizer applications were altered as follows: Calurea, $\mathrm{KNO}_{3}$ and Calnitro were reduced by onethird; Cottonseed meal and castor pomace reduced by one-fourth.

In the fall, measurements were made as usual. From time to time the soil was sampled for reaction and fertility tests. On April 2, 1935, all trees in the outside rows, and every other tree in the center row, were cut out, leaving six per frame. As the trees by this time were getting beyond the age of transplant bed stock, consideration of their later development is reserved for another publication.

The results from the first three growing seasons are given in Tables 11 and 12. Unfortunately, there were no untreated frames for comparison. This omission is of less consequence in the case of a crop like tobacco which would do practically nothing without fertilization. But for pines which have low requirements, it is desirable to determine whether or not the treatment is beneficial. One is never certain whether the best growth is actually superior, or whether it is merely normal, and the other treatments are below normal.

There was one more disturbing factor in connection with these frames. An apple tree near frame No. 1 offered so much competition that the pines nearest the tree were definitely handicapped. The apple tree roots were able to penetrate the frame from below, and even though the roots were severed once, the original handicap could not easily be overcome.

As seen in Table 11, PK was the best treatment in every case, and NK

Table 11. Meight, Neenle Length and Soll Tests Windsor Soil Frames. Red Pine

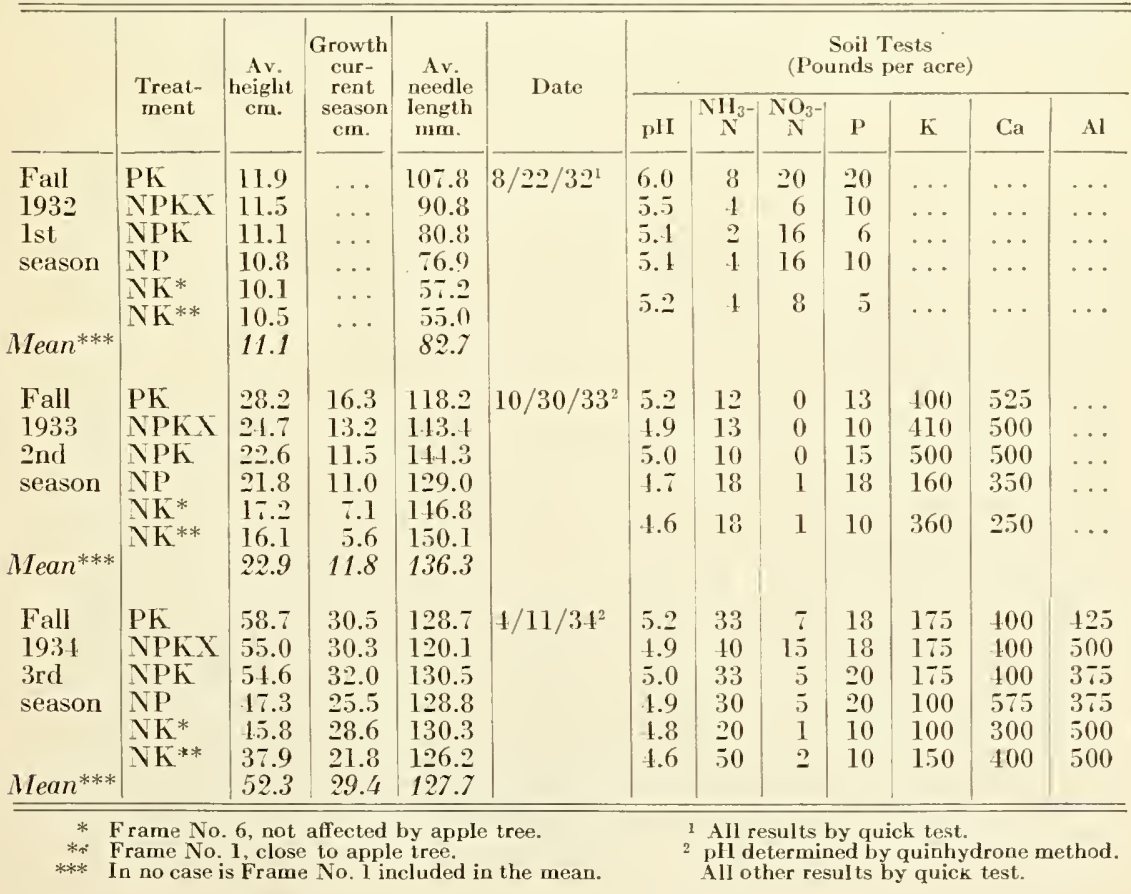


was the poorest. Because of the pronounced effect of the apple tree on the NK frame No. 1, its results are not averaged in with the others. For all three seasons the identical order was maintained with respect to height, although in the third growing season, the NPK treatment made the most growth. Needle length was strikingly variable the first year; but was very uniform the third year.

The acidity of the soil varied inversely with the yield. Since red pine prefers an acid soil it is believed that this correlation with acidity is merely a coincidence. This soil was low in available phosphorus and the growth of the trees substantiates the findings of the soil tests.

The weights of the trees removed from these frames are given in Table 12. In part A, the green and dry weights of approximately 30 trees cut off at the ground line yield reliable data as to the amount of tree growth up

Table 12. Weight of Red Pine Trees Removed from Windsor Soil Frames

A. April 16, 1934

\begin{tabular}{|c|c|c|c|c|c|c|c|}
\hline \multirow{3}{*}{ Treatment } & \multicolumn{3}{|c|}{ Cut Trees } & \multicolumn{4}{|c|}{$\begin{array}{l}\text { Average of } 5 \text { pulled trees } \\
\text { Dry weight, g. }\end{array}$} \\
\hline & \multirow{2}{*}{$\begin{array}{l}\text { No. of } \\
\text { trees }\end{array}$} & \multirow{2}{*}{\multicolumn{2}{|c|}{$\begin{array}{l}\text { Av. weight per tree } \\
\begin{array}{ll}\text { Green } & \text { Dry } \\
\text { g. } & \text { g. }\end{array}\end{array}$}} & \multirow{2}{*}{ Tops } & \multirow{2}{*}{ Roots } & \multirow{2}{*}{ Total } & Tops \\
\hline & & & & & & & Roots \\
\hline PK & 31 & 46.1 & 18.6 & 98.0 & 19.0 & 117.0 & 5.16 \\
\hline NPKX & 29 & 45.1 & 18.0 & 95.5 & 19.6 & 115.1 & 4.87 \\
\hline NPK & 31 & 36.2 & 14.4 & 113.0 & 19.5 & 132.5 & 5.79 \\
\hline NP & 31 & 29.2 & 11.0 & 70.2 & 17.2 & 87.4 & 4.08 \\
\hline $\mathrm{NK}^{*}$ & 29 & 24.0 & 9.8 & 68.0 & 14.5 & 82.5 & 4.69 \\
\hline $\mathrm{NK}^{* *}$ & 30 & 17.7 & 7.1 & 64.0 & 10.5 & 74.5 & 6.10 \\
\hline Mean**** & & 36.1 & 14.4 & 88.9 & 18.0 & 106.9 & 4.92 \\
\hline$\frac{\text { Green wt. }}{\text { Dry wt. }}$ & \multicolumn{3}{|c|}{ 2. 48} & \multicolumn{4}{|c|}{2.04} \\
\hline
\end{tabular}

B. April 2, 1935

\begin{tabular}{|c|c|c|c|}
\hline Treatment & $\begin{array}{c}\text { Frame } \\
\text { No. }\end{array}$ & $\begin{array}{c}\text { No. of } \\
\text { trees }\end{array}$ & $\begin{array}{c}\text { Green wt. } \\
\text { g. } \\
\text { Av. } \\
\text { g. }\end{array}$ \\
\hline NPK & $\begin{array}{l}4 \\
9\end{array}$ & $\begin{array}{l}29 \\
29\end{array}$ & $\left.\begin{array}{l}169.4 \\
169.6\end{array}\right\} 169.5$ \\
\hline NPKX & $\begin{array}{r}5 \\
10\end{array}$ & $\begin{array}{l}30 \\
28\end{array}$ & $\left.\begin{array}{l}174.3 \\
153.7\end{array}\right\} 164.0$ \\
\hline PK & $\begin{array}{l}8 \\
3\end{array}$ & $\begin{array}{l}28 \\
30\end{array}$ & $\left.\begin{array}{l}170.0 \\
149.8\end{array}\right\} 159.9$ \\
\hline NP & $\begin{array}{l}7 \\
2\end{array}$ & $\begin{array}{l}29 \\
24\end{array}$ & $\begin{array}{r}142.2\} 142.2 \\
97.5\} \ldots .\end{array}$ \\
\hline $\begin{array}{l}\text { NK } \\
\text { Mean }\end{array}$ & $\begin{array}{l}6 \\
1\end{array}$ & $\begin{array}{l}30 \\
28\end{array}$ & $\begin{array}{r}133.0\} 133.0 \\
89.8\}_{153.7}\end{array}$ \\
\hline
\end{tabular}

*Frame No. 6 not affected by apple tree.

** " " 1 close to apple tree.

**** In no case is Frame No. 1 included in the mean. 
to April, 1934. There was little difference between PK and NPKX, but trees on the other treatments averaged considerably smaller. The data on root size were taken from only five trees, and since the roots were merely pulled out, parts were broken off and lost. It so happened that trees from the NPK treatment were largest. The proportion of tops to roots was highest in the NPK and lowest in the NP. Other observations have shown an indication for the untreated plots to have the lowest proportion of tops to roots, which of course is a desirable characteristic in field planting.

Additional trees were cut out a year later, and the green weights of those removed are given in Part B of Table 12. Here we see that NPK has produced the largest trees, and PK has dropped to third place. All the way through, NK has produced the smallest plants, indicating the need for P in this soil when the other elements are supplied in abundance. The competing effect of the apple tree definitely extended to frame No. 2, so that the data from neither 1 nor 2 are included in the average. The fact that NP was inferior to $\mathrm{PK}$ in its effect upon growth indicates one of two things: either the soil is deficient in both $\mathrm{P}$ and $\mathrm{K}$ in relation to the soil nitrogen; or the amount of $\mathrm{N}$ addled was too great in proportion to the soil potassium.

Comparison of needle length to growth reveals that in 1932 the height increased slightly with needle length of that year. In 1933 growth was almost a perfect lineal function of the 1932 needle length. But the needle length in 1933 showed no correlation with growth that year, and only a slight indication of an inverse relationship with height of plants and with growth in 1934. Needle length in 1934 showed no correlation with 1934 growth. In the absence of needle counts, no conclusions can be drawn.

From the foregoing results it is evident that the deficiency of one element in the soil is reflected in the growth of red pines, provided the other necessary elements are present in abundance. However, the experiment does not tell us whether or not the trees would be benefited by the application of merely enough of the deficient element to balance the other elements naturally in the soil.

\section{Station Frames at New Haven}

A set of concrete soil frames on the Experiment Station grounds, which had been used some seven years for a wide variety of crops, was turned over to the writer in the spring of 1934 for use in tree studies. There are 48 frames, each measuring 25 by 25 inches, with the walls extending about 21 inches below the surface of the soil. There is no artificial bottom. The frames were filled with Cheshire fine sandy loam taken from the vicinity of the Experiment Station grounds. Treatments were as follows: O, P, $\mathrm{K}, \mathrm{PK}, \mathrm{N}, \mathrm{NP}, \mathrm{NK}, \mathrm{NPK}$; and the same repeated with lime. The lime was applied just once, the first year of the installation; all other treatments were made annually through 1933. Commencing in 1934. (the first year with trees) the treatments were given in two applications, half of the usual amount being applied in late April, and half in October. In order to avoid building up an accumulation of undesirable residue, materials which would leave no unwanted ions were used. These materials were urea, at the rate of 50 pounds of $\mathrm{N}$ per acrè, phosphoric acid $\left(\mathrm{H}_{2} \mathrm{PO}_{4} 85 \%\right)$ at the rate of 100 pounds $\mathrm{P}_{2} \mathrm{O}_{5}$ per acre, and potassium acetate $\left(\mathrm{KC}_{2} \mathrm{H}_{3} \mathrm{O}_{2}\right)$, 50 pounds $\mathrm{K}_{2} \mathrm{O}$ per acre. 
After spading under the rye which had been sown the previous fall as a cover crop, the soils were fertilized and then one series was planted to hand-selected red pine, 2-0 stock, 30 trees per plot. Red oak and sugar maple were planted in the other two series. Discussion of these species, however, will be reserved for another place.

\section{Results}

The trces were measured for total height in October, 1935, after two seasons' growth. 'Then, in the following spring, before growth commenced, they were thinned out so as to leave only nine per plot. The cut trees were weighed both green and dry. These results are given in Table 13. On

Table 13. Effect of Treatient on Growth of Red Pine.

New Haven Soll Frames.

\begin{tabular}{|c|c|c|c|c|c|c|c|c|c|c|c|}
\hline \multicolumn{5}{|c|}{ Spring 1936} & Fall 1935 & \multirow{2}{*}{\multicolumn{6}{|c|}{$\begin{array}{l}\text { Soil Tests, April } 1936 \\
\text { fbs. per acre }\end{array}$}} \\
\hline & \multicolumn{2}{|c|}{$\begin{array}{c}\text { Dry } \\
\text { Weight }\end{array}$} & \multicolumn{2}{|c|}{$\begin{array}{l}\text { Green } \\
\text { Weight }\end{array}$} & $\begin{array}{r}\text { Total } \\
\text { height }\end{array}$ & & & & & & \\
\hline $\begin{array}{l}\text { Treat- } \\
\text { ment }\end{array}$ & $\begin{array}{l}\text { Av. } \\
\text { per } \\
\text { tree } \\
\text { g. }\end{array}$ & $\begin{array}{c}\text { Total } \\
\text { for } \\
\text { plot } \\
\text { g. }\end{array}$ & $\begin{array}{l}\text { Av. } \\
\text { per } \\
\text { tree } \\
\text { g. }\end{array}$ & $\begin{array}{l}\text { Total } \\
\text { for } \\
\text { plot } \\
\text { g. }\end{array}$ & $\mathrm{cm}$. & $\mathrm{pH}$ & $\mathrm{NH}_{3}-\mathrm{N}$ & $P$ & $\mathbf{K}$ & $\mathrm{Ca}$ & $\mathrm{Al}$ \\
\hline NK & 11.85 & 237 & 26.8 & 536 & 23.1 & 5.25 & 5 & 15 & 200 & $<400$ & $>500$ \\
\hline & 10.63 & 202 & 24.7 & 4 & 21 & $5 .:$ & 10 & 200 & 150 & 600 & 400 \\
\hline $\mathrm{K}$ & 9.52 & 200 & 21.7 & 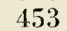 & 22 & 5.7 & 10 & 25 & 60 & 6 & 375 \\
\hline $\mathrm{O}$ & 9.47 & 199 & 21.5 & 453 & 21 . & 5.50 & 15 & 30 & 125 & 550 & 375 \\
\hline $\mathrm{N}$ & 9.45 & 189 & 21.2 & 424 & 18 & & $<5$ & 20 & $<100$ & $<100$ & $>500$ \\
\hline NPK & 9.14 & 128 & 21.1 & 295 & 21.1 & 5.15 & 5 & 300 & 250 & 450 & 425 \\
\hline PK & 9.05 & 190 & 21.1 & 4 & 21 & 5. & 6 & 17 & 5 & 850 & 175 \\
\hline NP & 8.90 & 178 & 20.2 & 405 & 18.3 & 4.85 & 15 & 120 & 125 & 3500 & 100 \\
\hline$A v$. & 9.75 & 190 & 22.3 & 435 & 21.1 & 5.33 & 9 & 108 & 256 & 925 & 356 \\
\hline LNP & 8.38 & 131 & 19.3 & 31 & 20.3 & & 15 & 120 & 125 & 3500 & 100 \\
\hline LNK & 8.2 & 115 & 18.6 & 26 & 18 & & $<5$ & 30 & 5 & 45 & 175 \\
\hline$I$ & 7.95 & 159 & 18.3 & 365 & 21.0 & 6.3 & 5 & 30 & 10 & 5000 & 50 \\
\hline LP & 7.90 & 158 & 18.2 & 364 & 20.3 & 6.10 & $<5$ & 300 & 1 & 50 & 50 \\
\hline $\mathrm{LI}$ & 7.57 & 159 & 17.0 & 358 & 19.8 & & $<5$ & 30 & 50 & 5000 & 35 \\
\hline LI & 7.40 & 148 & 17.1 & 342 & 19.1 & 5.80 & 5 & 15 & 175 & 1750 & 200 \\
\hline LPK & 7.21 & 137 & 16.5 & 314 & 17.9 & 6.32 & 5 & 275 & 60 & 5000 & 35 \\
\hline LNPK & 7.06 & 113 & 16.4 & 263 & 18.4 & 6.03 & 6 & 175 & 500 & 4500 & 100 \\
\hline$A v$. & 7.71 & 140 & 17.7 & 322 & 19.5 & 6.10 & 6 & 122 & 331 & 4281 & 93 \\
\hline
\end{tabular}

the basis of dry weight of the cut trees, which is the most reliable figure given, all of the limed plots produced smaller trees than the unlimed plots. This could be seen by careful ocular observation before the trees were removed. It should be noted also that only three of the treatments were superior to the untreated plot, and only two of these were significant: NK, 25 percent, and P, 12 percent. Perusal of the soil test data shows wide variations in the amount of available plant nutrients, but no correlations whatever with size of plant except that of $\mathrm{pH}$. All of the limed plots were less acid than the unlimed, although the differences in some cases are very slight.

Measurements of total height were again made in the fall of 1936; and in April, 1937, all trees were removed, taking as much root as possible without attempting to get all of the fine roots. The data in Table 14 show the results of the final season's growth. 


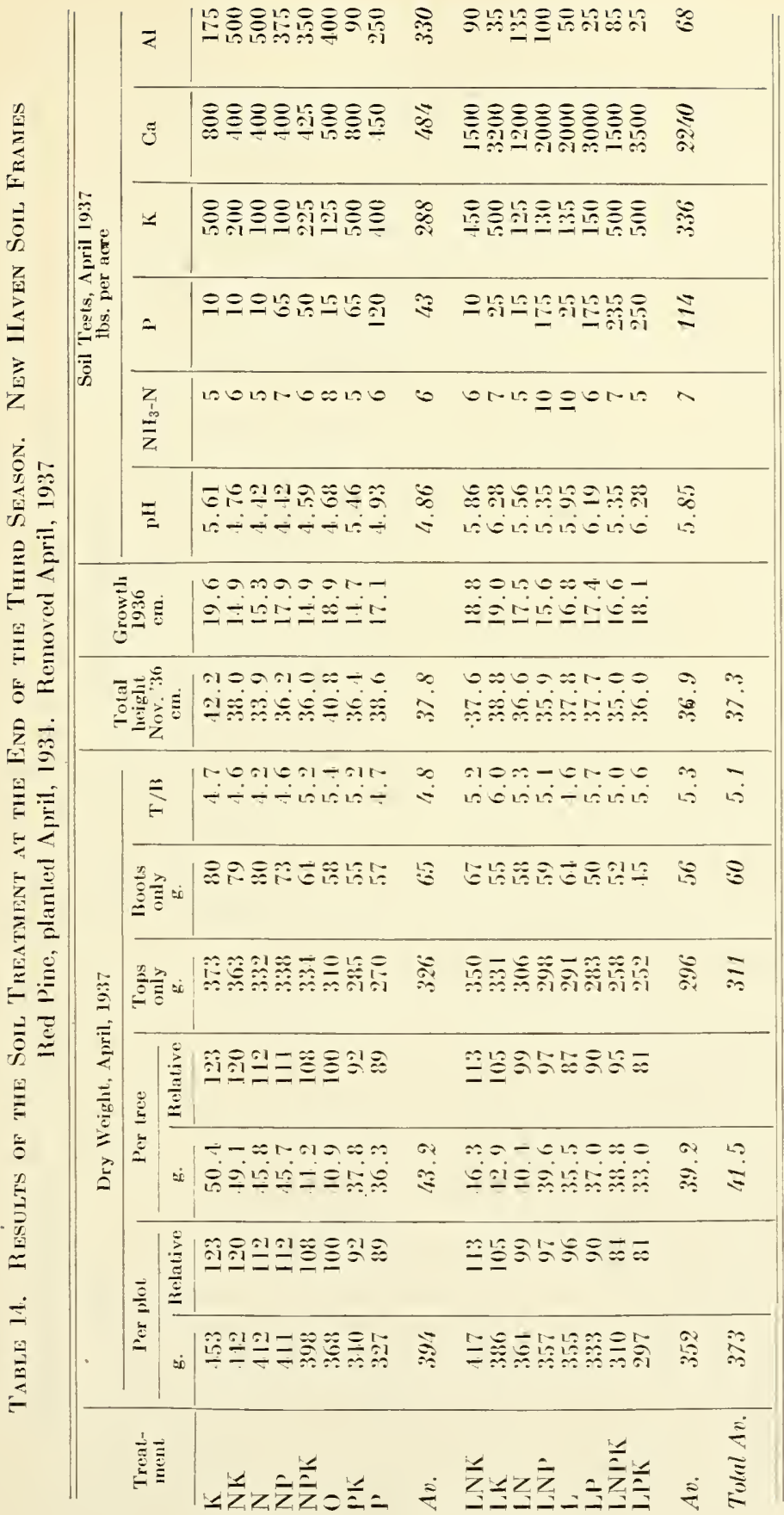


The treatments are arranged in order of decreasing dry weight per plot. One notes that the unlimed series K, alone or with N, produced larger plants than where $\mathrm{P}$ was present. The two poorest plots contained $\mathrm{P}$ without N. Five of the treatments appeared to give results superior to the no-treatment frame, as far as total weight or weight per tree is concerned. On the basis of height, only $\mathrm{K}$ was superior to the no-treatment, and the same thing may be said for the 1936 growth. In fact, on the basis of either tolal heighl or growth, little can be said in favor of soil fertilization. The top-root ratio data $(\mathrm{T} / \mathrm{R})$ is interesting in that the highest proportion of top to root occurred in the no-treatment frame, while the second highest proportion was found in the NPK and the PK frames, both of which were, perhaps, more nearly balanced in their essential nutrient supply than any of the others. The low proportion of tops to roots in the $\mathrm{N}$ treatment is contrary to the usual behavior of plants, and the reason is not clear. Possibly the acidity of the soil is a contributing factor. At no time since the trees were planted have soil tests indicated more than 10 to 15 pounds of either ammonia or nitrate nitrogen in any of the treatments. Usually the amount is less than five pounds (2.5 p.p.m.).

With respect to the limed series, we observe a similarity but not a duplication of the order of treatment in producing large plants. Lime alone gave the smallest proportion of tops to roots, while the treatments giving the three highest proportions contained no $\mathrm{N}$. On the whole, the limed series trees were smaller than the unlimed. On the other hand, the limed trees averaged a larger proportion of top to root.

In looking over the soil test data, one may observe that the average $\mathrm{pH}$ value and the $P, K$ and $C a$ contents are higher in the limed series than in the unlimed series. The action of the lime in taking the aluminum out of solution is clearly shown. All plots receiving $\mathrm{N}$ were more acid, and higher in aluminum, than those without $\mathrm{N}$, owing to the formation of relatively large amounts of nitric acid with insufficient bases to neutralize it. In all cases, the treatments containing $\mathbf{P}$ are found in the lower part of the list, although it will be recalled that in the preceding year the $\mathrm{P}$ treatment was second best.

From the foregoing results with red pine, one must conclude that under the conditions of the experiment:

1. The trees did better without lime.

2. In almost all cases of direct comparison of treatments, the trees on the more acid soil were the larger.

3. The presence of large amounts of $\mathbf{P}$ in the soil was, on the whole, associated with the smaller trees.

4. The presence of large amounts of aluminum in the soil was not harmful.

5. On this soil, the best treatments were $\mathrm{K}, \mathrm{NK}, \mathrm{N}$ and LNK. The poorest were LPK, LNPK, P and PK, in the order given.

6. At best, the differences in growth produced by the several treatments were not striking. The best treatment produced trees about 23 percent larger than did the untreated soil.

\section{SUBSEQUENT RESPONSE OF RED PINE IN THE FIELD}

\section{Trees from the Butter-tub Experiment}

After the trees were removed from the butter tubs in April, 1933, (see p. 725) they were taken to the Rainbow plantation and planted on the 
west end of Block 72 , set 3 by 3 feet, and two rows of large trees alternated with two rows of small trees. The south half of the area was fertilized with about 13 pounds of a mixture approximating 6-6-4, consisting of:

$\begin{array}{lr}\text { Cottonseed meal } & 5 \text { pounds } \\ \text { Castor pomace } & 4 \\ \text { Blood tankage } & 2 \\ \text { Precipitated bone } & 270 \mathrm{~g} . \\ \text { Muriate of potash } & 310 \mathrm{~g} . \\ \text { Ammophos "A" } & 136 \mathrm{~g} \text {. }\end{array}$

There were 38 trees, so that each tree received about three-fourths pound of fertilizer; the rate per acre was 1,574 pounds.

The survival count made at the end of the growing season showed the following results:

$\begin{array}{lcc} & \text { Unfertilized } & \text { Fertilized } \\ \text { Total Planted } & 38 & 38 \\ \text { Dearl } & 9 & 1.1 \\ \text { Living } & 29 & -4 . \\ \text { Survival percent } & 76.3 & 63.1\end{array}$

There is no question but that the application was too heavy, although the losses of the unfertilized portion were rather high also.

No fertilizer was used in 1931, but in 1935 an 11-6-6 mixture consisting of the following was applied at the rate of 100 pounds per acre:

$\begin{array}{lr}\text { Sulfate of anmonia } & 525 \mathrm{~g}, \\ \text { Dried ground fish } & 718 \%, \\ \text { Precipitated bone } & 90 ", \\ \text { Sulfate of potash } & 165 ",\end{array}$

Measurements of total height were made in the fall of 1935 and 1937 with the results given in Table 15 . It is apparent that the larger trees

Table 15. Growth of Butter Tub Red Pines in the Field

(Inches)

\begin{tabular}{|c|c|c|c|c|}
\hline & \multicolumn{2}{|c|}{ Not fertilized in the field } & \multicolumn{2}{|c|}{ Fertilized in the field } \\
\hline & Small trees & Large trees & Small trees & Large trees \\
\hline $\begin{array}{l}\text { Av. height, Fall } 1932 \\
\text { “" } \\
\text { Leader growth (3 seasons) } \\
\text { Mean }\end{array}$ & $\begin{array}{rr}1.7 & -2.1 \\
51.0 & 16.1 \\
15.3 & 9.0 \\
12.8\end{array}$ & $\begin{array}{cc}3 & 4 \\
10.6 & 10.3 \\
24.7 & 23.0 \\
14.1 & 12.7 \\
13.4\end{array}$ & $\begin{array}{rr}1.7 & \frac{2}{7.1} \\
19.7 & 22.0 \\
14.0 & 14.9 \\
14.4\end{array}$ & $\begin{array}{cc}3 & 4 \\
10.6 & 10.3 \\
28.7 & 17.7 \\
18.1 & 7.4 \\
15.0\end{array}$ \\
\hline Leader growth 1936-37 & $22.7 \quad 15.9$ & $22.4 \quad 18.7$ & $17.3 \quad 18.6$ & $24.2 \quad 16.0$ \\
\hline Mean & 19.47 & 20.50 & 17.91 & 21.8 \\
\hline Mean & \multicolumn{2}{|c|}{19.90} & \multicolumn{2}{|c|}{19.68} \\
\hline $\begin{array}{l}\text { Mean, all small trees } \\
\text { Mean, all large trees }\end{array}$ & $\begin{array}{l}18.82 \\
21.09\end{array}$ & & & \\
\hline
\end{tabular}

made somewhat more growth in the field than did the initially snall trees. Furthermore, it is apparent that the use of fertilizer in the field was but slightly beneficial. During the last two seasons only the larger trees showed a response to field fertilization. At this stage in the life history of the tree, we are not concerned with the size of root, for it is the top growth that interests us. Therefore, we are justified in measuring top growth only. 
The experiment is being contimued and measurements will be made approximately at 1 wo-year intervals.

\section{Trees from the Windsor Transplant Beds}

As stated on page 736,35 average trees from the three plots of eight different treatments were selected in April, 1933, and taken to the Rainbow Plantation where they were planted 3 by 3 feet. The planting arrangement consisted of four blocks of trees, each block measuring 24 by 48 feet and containing two rows of trees from each treatment. The treatments were staggered in order to reduce the effect of any soil differences. Thus, there were 32 "plots", each plot containing 24 trees. After planting, the second and fourth blocks or series, plots 9 to 16 and 25 to 32 respectively, were fertilized with the following mixture:

$$
\begin{array}{ll}
\text { Fish } & 22 \text { pounds } \\
\text { Ammophos "A" } & 1 \\
\text { Precipitated bone } & 1.5 \\
\text { Sulfate of potash } & \frac{2}{26.5} \text { to } 1,152 \text { sq. } \mathrm{ft} .
\end{array}
$$

This was approximately a $7-10-5$ mixture applied at the rate of 1,000 pounds per acre.

As in the previous experiment, nothing was done to the plots in 1934 , but in April, 1935, the following material was applied to series 2 and a like amount to series 4 :

$$
\begin{array}{lr}
\text { Fish } & 2,300 \mathrm{~g} . \\
\text { Sulfate of ammonia } & 1,680 \\
\text { Precipitated bone } & 288 \\
\text { Sulfate of potash } & \mathbf{5 2 8} \\
& \overline{4,796} \text { g. to } 1,152 \mathrm{sq} . \mathrm{ft} .
\end{array}
$$

This is an 11-6-6 mixture applied at the rate of 400 pounds per acre.

Measurements of tree height were taken in the fall of 1935 and again in 1937, with the results given in Table 16. Only the total growth for the five years is shown. Considering first the mean growth of all trees, we observe some differences based upon previous treatment in the nursery. Five of the treatments were significantly better and one poorer than the untreated plants, regardless of the size of the plants when they were removed from the nursery. These results are in agreement with those reported by Némec (16) and Leiningen-Westerburg (6) who have found that a fertilized transplant is much better able to survive and usually grows faster when set out than an unfertilized plant. The data in Table 16 are not sufficiently conclusive to permit one to say which fertilizer is best.

With respect to the effect of field fertilization, the data show a positive response averaging 3 inches or about 6 percent gain over the unfertilized portion. The excellent response of the urea-treated trees, about 22 percent, is in decided contrast to the negative results obtained with the $\mathrm{NaNO}_{3}$ 
-treated trees. These differences are difficult to explain and should be confirmed by further experimentation before definite conclusions can be drawn.

Table 16. Mean* Growth of Windsor Traysplant Red Pines in the Field at Rainbow

\begin{tabular}{|c|c|c|c|c|c|c|}
\hline \multirow{2}{*}{$\begin{array}{l}\text { Treatment } \\
\text { in the } \\
\text { nursery }\end{array}$} & \multirow{2}{*}{$\begin{array}{l}\text { Original } \\
\text { height } \\
\text { inches }\end{array}$} & \multicolumn{2}{|c|}{$\begin{array}{l}\text { Mean } 5 \text {-year growth of } \\
\quad \text { all trees, 1933-37 }\end{array}$} & \multirow{2}{*}{$\begin{array}{l}\text { Not } \\
\text { fertilized } \\
\text { in the field } \\
\text { inches }\end{array}$} & \multirow{2}{*}{$\begin{array}{l}\text { Fertilized } \\
\text { in the field } \\
\text { inches }\end{array}$} & \multirow{2}{*}{$\begin{array}{l}\text { Difference } \\
\text { inches }\end{array}$} \\
\hline & & inches & relative & & & \\
\hline LNPK & 9.3 & 52.5 & 111 & 51.6 & 53.5 & +1.9 \\
\hline Urea & 9.5 & 52.0 & 110 & 46.9 & 57.0 & +10.1 \\
\hline Am. Sulf. & 8.8 & 51.6 & 109 & 50.4 & 51.9 & +1.5 \\
\hline Fish & 10.3 & 51.5 & 109 & 50.4 & 52.4 & $\begin{array}{r}+2.0 \\
+2.0\end{array}$ \\
\hline NPK & 9.0 & 50.8 & 107 & 19.3 & 52.1 & $\begin{array}{r}2.8 \\
+2\end{array}$ \\
\hline $\mathrm{NaNO}_{3}$ & 9.3 & 18.0 & 101 & 50.0 & -16.0 & -4.0 \\
\hline Check & 8.7 & 47.4 & 100 & 46.5 & 483 & +1.8 \\
\hline Urea PK & 9.5 & 46.6 & 98 & 11.2 & 19.1 & +5.2 \\
\hline$A v$ & 9.3 & $\ldots$ & $\ldots$ & 48.7 & 51.7 & +3.0 \\
\hline
\end{tabular}

*Mean $=\frac{\sum \text { growth of each tree }}{\text { no. of trees }}$

\section{REQUIREMENTS OF NURSERY SEEDLINGS AND TRANSPLANTS}

As another approach to the problem of nursery fertilization, one may analyze the plants and determine how much of the several elements are actually absorbed. Such procedure has its limitations, of course, for the composition of the plant tells one nothing as to the amount of nutrients necessary in the soil to enable the plant to make a normal growth. Also, one must allow for the possibility of huxury consumption, a process which almost ahways occurs in the presence of targe amounts of soluble materials. Nevertheless, there is an advantage in knowing what the plant does lake up in the course of normal growth and development.

Although there has been considerable work done along this line in Europe, the field has remained practically untouched in this country. Therefore, in the fall of 1935 and again in 1936, plants were collected from the Peoples Forest nursery for analysis. All of the plants in a measured area were carefully removed, counted, dried and weighed, and later analyzed. By such a procedure it was hoped to oblain some idea of the requirements of various species at three age levels: 1-0, 2-0 and 2-1.

In order to determine the requirements per unit area, it is necessary to take into account the density of the stand which may vary tremendously in the case of seedbeds because of unevenness of germination and survival. It was observed that where uniformly spaced, a density of 80 to 90 trees per square foot was about ideal, particularly for pines. Spruce could stand greater crowding, possibly 125 trees. When the number reached 250 to 300 or more, the trees were obviously much too crowded. Density in the transplant bed depends primarily upon the planting practices followed in the particular nursery and is usually controlled by the type of planting board in use. The planting board at this nursery placed the plants in :foot rows, with 1.7 inches between trees and 4 inches between rows. At Windsor, the beds were 4 feet wide, with 1.6 inches between trees and 6 
inches between rows. Calculations of density according to several planting plans give the following results, along with which we present figures given by Manchard (7) in Germany:

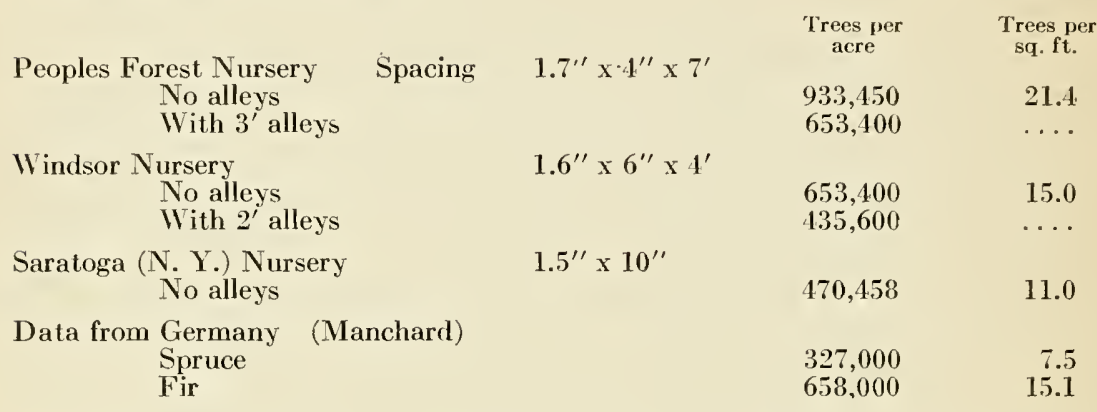

In Bohemia the practice in many nurseries is to plant only nine, and in some cases only four, trees to the square foot.

According to Süchting and Jessen (24) the net dry weight per unit area varies somewhat with density but not in proportion. On the other hand, size of the individual trees is greatly influenced by density, inversely of course. This was illustrated in Figures 110 and 111.

The results of the analyses are given in Tables 17 and 18. One may observe a marked difference between species, due partly to differences in percentage composition, and partly to the great variation in density of the stands. For example, in the 1-0 stock (1935) there were, as a fair average, about 225 Scotch pine trees per square foot, or 3,090 pounds of dry matter per acre. White pine, on the other hand, was much less dense and the individual trees were somewhat smaller in size. Scotch pine analyzed highest in $\mathrm{N}$ and showed the highest amount of nitrogen per acre. With respect to the other constituents, Scotch pine did not have the highest percentage composition, but it did have the largest amount per acre because of the greater quantity of dry matter.

When compared on the basis of 100 trees per square foot, the differences among species are considerably reduced. While this basis of comparison has its advantages, it is not necessarily any more correct, for were there only 100 trees instead of 225 , for example, each individual tree would be considerably larger.

Quite striking are the relatively high amounts in the 2-0 stock. The percentage composition is generally less than in the $1-0$ stock but the much greater size of the trees, together with the relatively high density, makes for a high dry matter yield and consequently high requirements. Unfortunately, it was not possible to have all species represented in all age classes. The phosphorus content of Norway spruce was high in both years, but because of the wide variation in the dry weight of the two spruces, nothing definite can be said respecting the demands of one specie in relation to those of the other. While larch appeared to have a higher requirement than spruce in the 1-0 stock, the relationship is just the reverse in the 2-0 stock. The calcium content of the spruce was definitely higher than that of the pines in all three age classes. 
Table 17. Peoples Forest Nursery

Composition and Aurount Per Acre of Seedungs and Transplants. 1935 Comparison of Species

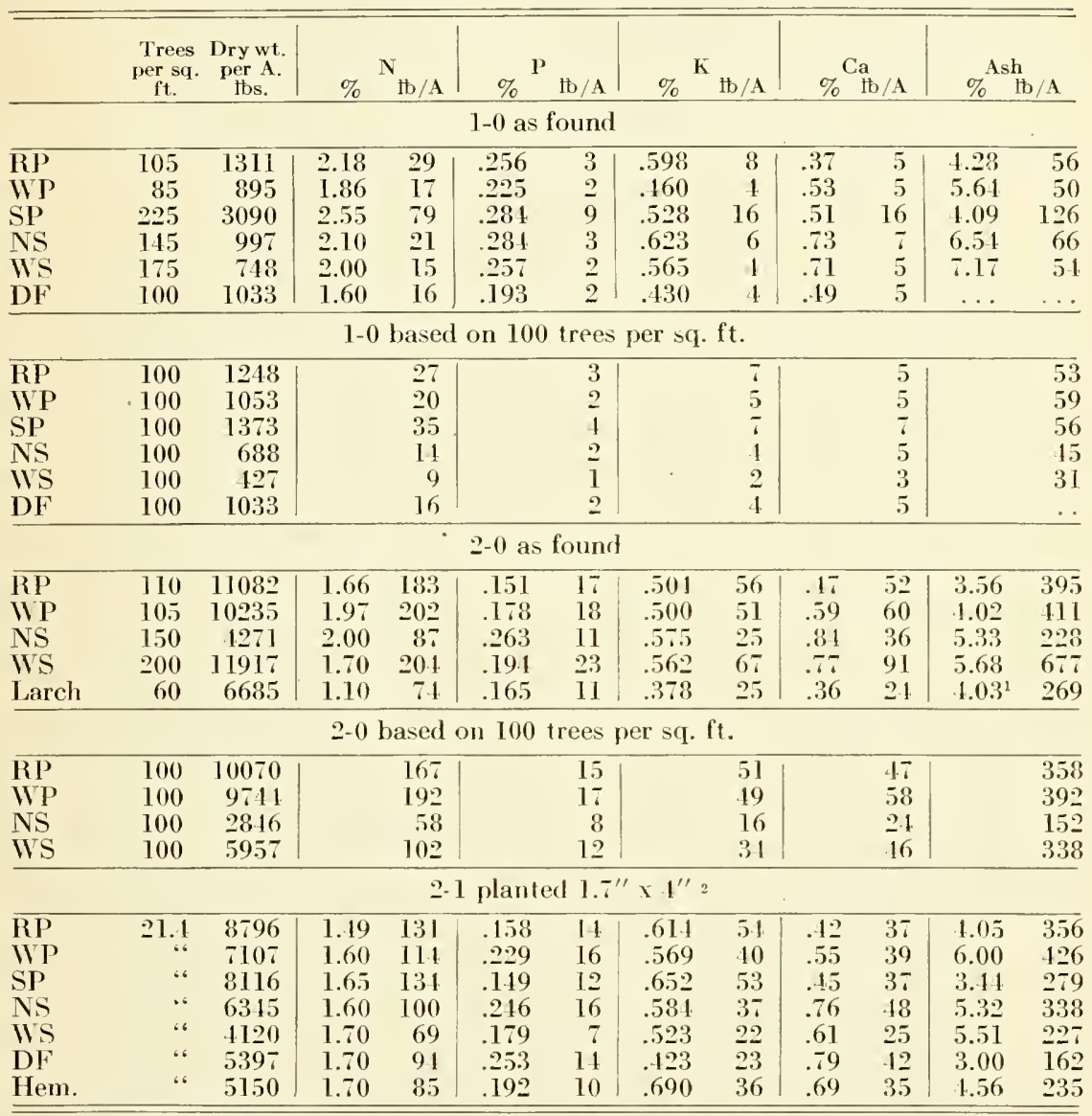

1 Av. of large and small.

2 Allowing no alleys.

Because of the wider spacing of the 2-1 stock, the dry weight and consequently the nutrient content were, for the most part, less than in the case of the 2-0 stock. If allowed to remain a second year in the transplant bed, as is frequently the case, the dry matter would considerably exceed that of the 2-1 age class. Some idea of these differences may be obtained from the following data:

$\begin{array}{cccc}\text { Age of stock } & \begin{array}{c}\text { Red pine } \\ \text { (Lunt) }\end{array} & \begin{array}{c}\text { dry weight per tree in grams } \\ \text { Norway spruce } \\ \text { (Manchard) }\end{array} & \begin{array}{c}\text { Fir (A. pectinata) } \\ \text { (Manchard) }\end{array} \\ 1-0 & 0.15 & 0.18 & 0.17 \\ 2-0 & 1.10 & 1.18 & 0.78 \\ 2-1 & 3.90 & 8.67 & 2.93 \\ 2-2 & 10.40 & 19.91 & 11.40 \\ 2-3 & 42.00 & \ldots . . & \ldots\end{array}$


Table 18. Peoples Forest Nursery

Composition and Amount Per Acre of Seedlings and Transplants. 1936 Couparison of Species

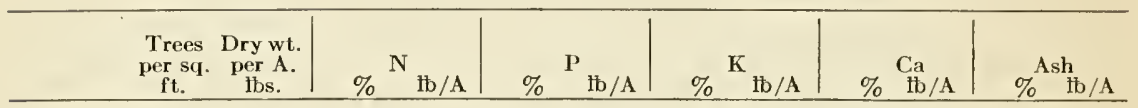

$1-0$ as found

\begin{tabular}{lrr|rr|rr|rr|rr|rr}
\hline RP & 200 & 3110 & 1.71 & 53 & .285 & 9 & .692 & 22 & .390 & 12 & 4.45 & 138 \\
WP & 160 & 2352 & 1.58 & 37 & .270 & 6 & .495 & 12 & .421 & 10 & 5.01 & 119 \\
SP & 375 & 3398 & 2.21 & 75 & .291 & 10 & .627 & 21 & .417 & 14 & 5.83 & 198 \\
NS & 200 & 1340 & 2.12 & 28 & .380 & 5 & .688 & 9 & .751 & 10 & 4.80 & 64 \\
Larch & 200 & 2640 & 1.31 & 35 & .271 & 7 & .720 & 19 & .350 & 9 & 4.59 & 121 \\
\hline
\end{tabular}

1. 0 based on 100 trees per sq. $\mathrm{ft}$.

\begin{tabular}{lcr|r|r|r|r|r}
\hline RP & 100 & 1555 & 27 & 4 & 11 & 6 & 69 \\
WP & ، & 1469 & 23 & 4 & 7 & 6 & 74 \\
SP & ، & 907 & 20 & 3 & 6 & 4 & 53 \\
NS & 6 & 1320 & 14 & 3 & 5 & 5 & 32 \\
Larch & “ & 17 & 4 & 10 & 5 & 61 \\
\hline
\end{tabular}

$2-0$ as found

\begin{tabular}{lrr|rr|rr|rr|rr|rr}
\hline RP & 120 & 13066 & 1.58 & 206 & .187 & 24 & .541 & 71 & .378 & 49 & 4.25 & 555 \\
WP & 115 & 6624 & 1.84 & 122 & .184 & 12 & .617 & 41 & .398 & 26 & 3.10 & 205 \\
SP & 140 & 12797 & 1.93 & 217 & .197 & 25 & .580 & 71 & .397 & 51 & 3.80 & 486 \\
NS & 184 & 9446 & 1.59 & 150 & .228 & 22 & .615 & 61 & .762 & 72 & 5.77 & 5.15 \\
WS & 175 & 6250 & 1.60 & 100 & .187 & 12 & .595 & 37 & .685 & 43 & 5.21 & 326 \\
\hline
\end{tabular}

2-0 based on 100 trees per sq. $\mathrm{ft}$.

\begin{tabular}{lcr|r|r|r|r|r}
\hline RP & 100 & 10886 & 172 & 20 & 59 & 41 & 463 \\
WP & $“ 6$ & 5760 & 106 & 11 & 36 & 23 & 179 \\
SP & N & 9139 & 176 & 18 & 53 & 36 & 347 \\
NS & “ & 5136 & 82 & 12 & 33 & 39 & 296 \\
WS & “ & 3571 & 57 & 7 & 21 & 24 & 186 \\
\hline
\end{tabular}

2-1 planted $1.7^{\prime \prime} \times 4^{\prime \prime}$. No alleys.

\begin{tabular}{lcr|rr|rr|rr|rr|rr}
\hline $\mathrm{RP}$ & 21.4 & 7251 & 1.52 & 110 & .191 & 14 & .527 & 33 & .279 & 20 & 4.28 & 310 \\
$\mathrm{WP}$ & $“$ & 8313 & 1.34 & 112 & .202 & 17 & .596 & 50 & .314 & 29 & 5.55 & 463 \\
$\mathrm{SP}$ &. & 6777 & 1.54 & 105 & .185 & 13 & .599 & 41 & .377 & 26 & 4.10 & 278 \\
$\mathrm{NS}$ & $“$ & 2201 & 1.61 & 35 & .235 & 5 & .423 & 9 & .690 & 15 & 6.14 & 135 \\
\hline
\end{tabular}

Typical trees from the three age classes representative of the 1935 sampling are shown in Fig. 113. In the 1-0 and 2-1 groups, Norway spruce (NS). was larger than white spruce (WS); but in the 2-0 group, white spruce was larger than Norway. Apparently this was merely a coincidence, for in the 1936 sampling 2-0 NS was larger than 2-0 IVS. (See dry weight per acre on the basis of 100 trees per square foot. Tables 17 and 18). 


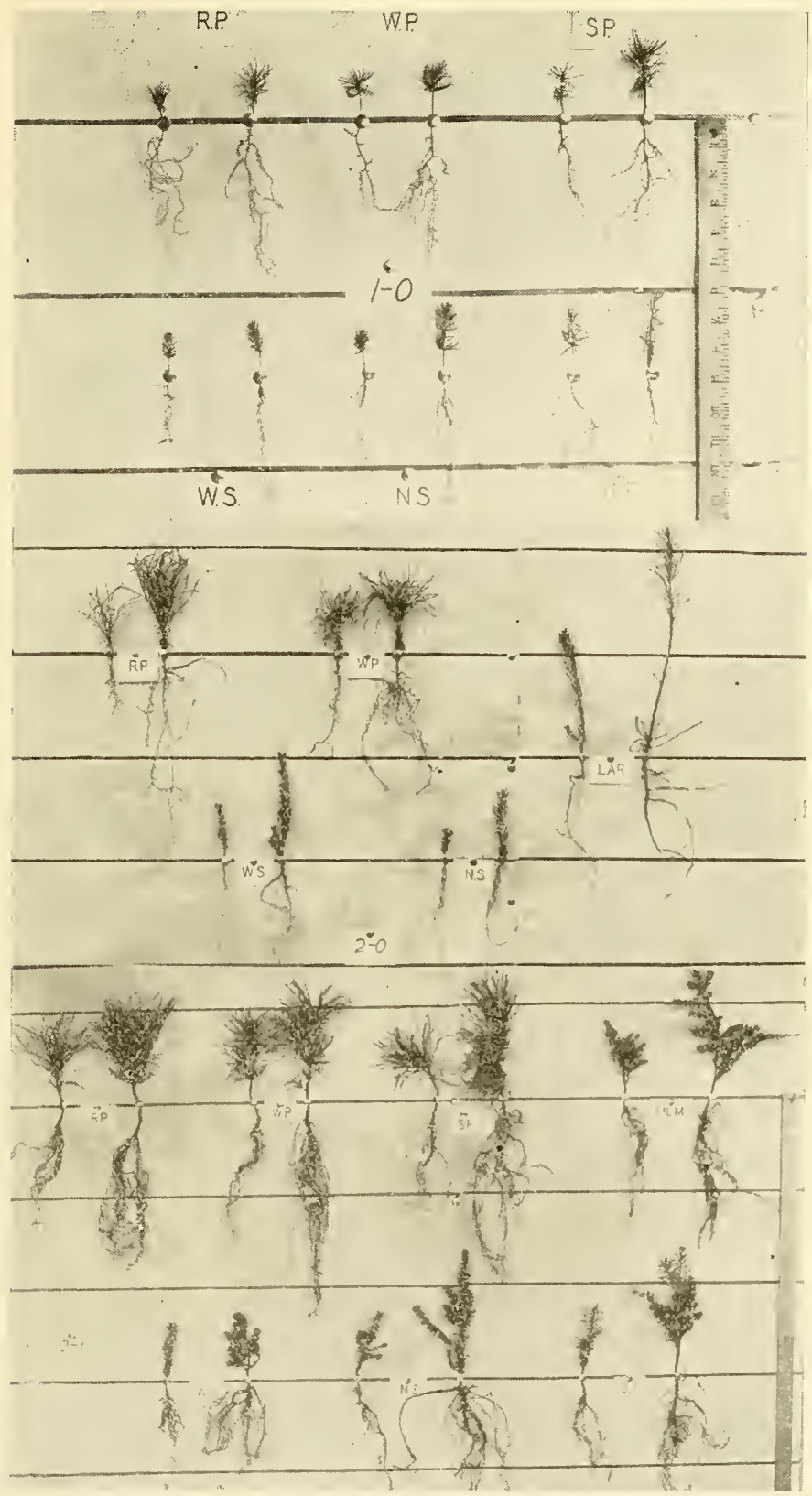

Figure 113. Representative small and large seedlings trom Peoples Forest Nursery.

Top: 1-0 age class; Middle: $2-0$ age class; Bottom: $2-1$ age class.

$\mathrm{RP}-$ red pine IVP - white pine SP-Scotch pine WS -white spruce
NS-Norway spruce

DF-Douglas fir

Lar.-larch

Hem.-hemlock 
Table 19. Peoples Forest Nursery

Annual Nutrient Requirements for Nursery Stock.

Pounds per Acre

\begin{tabular}{|c|c|c|c|c|c|c|c|c|}
\hline & & $\mathrm{N}$ & $\mathrm{P}$ & $\mathrm{P}_{2} \mathrm{O}_{5}$ & K & $\mathrm{K}_{2} \mathrm{O}$ & $\mathrm{Ca}$ & $\mathrm{CaO}$ \\
\hline \multirow[t]{2}{*}{ RP } & $\begin{array}{l}1-0 \\
2-0 \\
2-1\end{array}$ & $\begin{array}{r}41 \\
154 \\
84\end{array}$ & $\begin{array}{r}6 \\
14 \\
10\end{array}$ & $\begin{array}{l}14 \\
32 \\
23\end{array}$ & $\begin{array}{l}15 \\
19 \\
34\end{array}$ & $\begin{array}{l}18 \\
59 \\
41\end{array}$ & $\begin{array}{r}9 \\
42 \\
18\end{array}$ & $\begin{array}{l}13 \\
59 \\
2.5\end{array}$ \\
\hline & & 279 & 30 & 69 & 98 & 118 & 69 & 97 \\
\hline \multirow[t]{2}{*}{ WP } & $\begin{array}{l}1-0 \\
2-0 \\
2-1\end{array}$ & $\begin{array}{r}27 \\
135 \\
82\end{array}$ & $\begin{array}{r}4 \\
11 \\
14\end{array}$ & $\begin{array}{r}9 \\
25 \\
32\end{array}$ & $\begin{array}{r}8 \\
38 \\
36\end{array}$ & $\begin{array}{l}10 \\
46 \\
43\end{array}$ & $\begin{array}{r}8 \\
35 \\
26\end{array}$ & $\begin{array}{l}11 \\
49 \\
26\end{array}$ \\
\hline & & 211 & 29 & 66 & 82 & 99 & 69 & 36 \\
\hline \multirow[t]{2}{*}{ SP } & $\begin{array}{l}1-0 \\
2-0 \\
2-1\end{array}$ & $\begin{array}{r}77 \\
170 \\
82\end{array}$ & $\begin{array}{r}10 \\
15 \\
9\end{array}$ & $\begin{array}{l}23 \\
34 \\
21\end{array}$ & $\begin{array}{l}19 \\
55 \\
36\end{array}$ & $\begin{array}{l}23 \\
66 \\
43\end{array}$ & $\begin{array}{l}15 \\
36 \\
23\end{array}$ & $\begin{array}{l}21 \\
50 \\
32\end{array}$ \\
\hline & & 329 & 34 & 78 & 110 & 132 & 74 & 103 \\
\hline \multirow[t]{2}{*}{ NS } & $\begin{array}{l}1-0 \\
2-0 \\
2-1\end{array}$ & $\begin{array}{l}25 \\
93 \\
53\end{array}$ & $\begin{array}{r}4 \\
12 \\
9\end{array}$ & $\begin{array}{r}9 \\
27 \\
21\end{array}$ & $\begin{array}{r}8 \\
35 \\
18\end{array}$ & $\begin{array}{l}10 \\
42 \\
22\end{array}$ & $\begin{array}{r}9 \\
45 \\
25\end{array}$ & $\begin{array}{l}13 \\
63 \\
35\end{array}$ \\
\hline & & 171 & 25 & 57 & 61 & 74 & 79 & 111 \\
\hline \multirow[t]{2}{*}{ WS } & $\begin{array}{l}1-0 \\
2-0 \\
2-1\end{array}$ & $\begin{array}{r}15 \\
137 \\
52\end{array}$ & $1 \frac{2}{5}$ & $\begin{array}{r}5 \\
37 \\
11\end{array}$ & $\begin{array}{r}4 \\
48 \\
16\end{array}$ & $\begin{array}{r}5 \\
58 \\
19\end{array}$ & $\begin{array}{r}5 \\
62 \\
17\end{array}$ & $\begin{array}{r}7 \\
87 \\
24\end{array}$ \\
\hline & & 204 & 23 & 53 & 68 & 82 & 84 & 118 \\
\hline
\end{tabular}

Formulae for Calculating Above Results:

$$
\begin{aligned}
& \mathrm{R}_{1}=\mathrm{a} \\
& \mathrm{R}_{2}=\mathrm{b}-\mathrm{a} \\
& \mathrm{R}_{3}=\mathrm{c}-\left(\frac{\mathrm{d}}{\mathrm{e}} \times \mathrm{b}\right)
\end{aligned}
$$

Where $R_{1}=$ Requirements for the Ist year (1-0 stock)

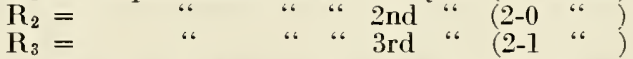

$$
\begin{aligned}
& \mathrm{a}=\text { amount of material contained in 1-0 stock } \\
& \mathrm{b}=\text { " " " " " } 20 \text { " " } \\
& \mathrm{c}=\text { " } \quad \text { " } \quad \text { " } \quad \text { ". } \\
& \mathrm{d}=\text { no. of trees per sq. ft. in transplant bed (2-1) } \\
& \mathrm{e}=\text { "." "." ". seedbeds (1-0 and 2-0) }
\end{aligned}
$$

The data in Table 19 differ from those tables in 17 and 18 in that while the latter give the actual composition, the former represent the net requirements for each year. In other words, to ascertain the requirements for the stock during the second year, one must subtract the amount of material present in the first year. In addition, for the third year, allowance must be made for differences in density, as indicated by the formulae at the bottom of Table 19. These calculations are based on the average composition for the two years represented in Tables 17 and 18. 
While in most instances the requirements for nutrients were low, high and medium for the 1-0, 2-0 and 2-1 stock, respectively, there are several cases in which this relationship does not hold. These are: Scotch pine-$\mathrm{N}$ and $\mathrm{P}$; white pine- $\mathrm{K}$. In the former cases, there was little difference in the demands made by 1-0 and 2-1 stock; in the latter case there was little difference between 2-0 and 2-1.

Comparison of these results with the finoings of other investigators is limited because of lack of similarity in species. However, comparable data on Scotch pine and Norway spruce are available and are given in Table 20. Excepting the data reported by Dulk and Schütze, which are

Table 20. Annual Reouirements of Nursery Stock According to Different Investigators

Pounds per Acre

\begin{tabular}{|c|c|c|c|c|c|c|}
\hline Investigator & $\mathrm{N}$ & $\mathrm{P}_{2} \mathrm{O}_{5}$ & $\mathrm{~K}_{2} \mathrm{O}$ & $\mathrm{CaO}$ & $\underset{\text { Dry }}{\text { matter }}$ & $\begin{array}{l}\text { DM per } \\
100 \text { trees } \\
\mathrm{g} .\end{array}$ \\
\hline \multicolumn{7}{|c|}{ Scotch Pine 1-0 } \\
\hline Dulk and Schütze & 96 & 39 & 71 & 7 & $\ldots$ & $\ldots$ \\
\hline Others & 62 & 22 & 27 & 67 & & $\ldots$ \\
\hline Manchard & $8 \overline{5}$ & 24 & 35 & 21 & 1028 & 63.3 \\
\hline Lunt & 77 & 23 & 23 & 21 & 3211 & 12 \\
\hline \multicolumn{7}{|c|}{ Norway Spruce 1-0 } \\
\hline Dulk and Schütze & & 31 & 36 & 77 & & \\
\hline von Schroeder & 21 & 7 & 12 & 12 & 1302 & 11.0 \\
\hline Manchard & 25 & 9 & 12 & 17 & 1292 & $1 \div .6$ \\
\hline Lunt & 25 & 9 & 10 & 9 & 1168 & 7.1 \\
\hline \multicolumn{7}{|c|}{ Norway Spruce 2-0 } \\
\hline von Schroeder & 117 & 49 & 58 & 71 & 10058 & 109 \\
\hline Manchard & 88 & 27 & 15 & 78 & 7183 & 118 \\
\hline Lunt & 93 & 27 & 12 & 63 & 6863 & 12 \\
\hline \multicolumn{7}{|c|}{ Norway Spruce 2-1 } \\
\hline von Schroeder* & 55 & 27 & 62 & 59 & 17867 & 275 \\
\hline Manchard & 79 & 21 & 33 & 93 & 6250 & 867 \\
\hline Lunt & 53 & 21 & 22 & 35 & 1275 & 208 \\
\hline
\end{tabular}

*Probably 3-0 instead of 2-1.

unusually high in every case, the agreement among the others is remarkably good, especially so in the case of Nanchard and the writer. Manchard obtained larger amounts of dry matter per acre and also per tree. This is due partly at least to the difference in density of the stand as shown on page 752 . It is probable, also, that the German nursery soil was in a higher state of fertility. Manchard's soil was a diluvial sand varying to loamy or moorish, slightly acid and of good fertility. In every case Mlanchard found a considerably higher calcium content and in some cases a higher potash content than did the writer.

It is interesting to compare the demands of the trees with the amount of nutrient material supplied in the fertilizers used in these studies. Accurate comparisons are impossible, of course, due to variations in the rate and 
completeness of solubility, possible losses by leaching, etc. Certain amounts of nutrients are furnished by the soil itself, and the question as to what proportion of the crop's needs should be supplied as fertilizer depends upon the crop and the soil. With ordinary farm crops, the larger part of the nitrogen needed is expected to come from the soil as a product of organic matter decomposition. Phosphorus is usually added in amounts in excess of the plant requirements for two reasons: the natural deficiency of $\mathrm{P}$ of many soils, and the low availability of $\mathrm{P}$ because of its fixation in the soil. The soil type largely governs the application of $K$, sandy and muck soils being much more deficient in that element than clays.

In the case of nursery stock, we have a situation in which there are no crop residues to return to the soil and, at least in the Northeast, usually a sandy soil with which to deal. According to the data in Table 20, the amount of material removed by the crops is considerable, particularly the 2-0 stock. Unless good quality manure is used rather generously, and unless circumstances permit the use of rotations with farm crops and ample opportunity to build up the soil between nursery crops, it is advisable to supply the larger part, if not all, of the tree's needs by the use of fertilizers. Kuhnert (5) states that an annual application of about 36 pounds of $\mathrm{P}_{2} \mathrm{O}_{5}, 36$ of $\mathrm{K}_{2} \mathrm{O}$ and 36 to 53 of nitrogen per acre, with an occasional application of lime, will serve to maintain the fertility of nursery soils.

Mitchell (9), from extensive pot experiments with Scotch pine and white pine seedlings, found that in sand cultures the optimum $\mathrm{N}$ concentration was 300 p.p.m., provided the other essential elements were present in abundance. This concentration is equivalent to about 60 p.p.m. $N$ in the soil, or 120 pounds per acre, assuming soil with a volume weight of 1.0. This figure is somewhat larger than those given in Table 20, a difference to be expected considering that one is comparing well-controlled pot cultures with field experiments.

The several treatments used at Peoples Forest Nursery furnjshed the following amounts of nutrients, the variation depending on the rate of application:

\begin{tabular}{|c|c|c|c|}
\hline Fertilizer & $\mathrm{N}$ & $\begin{array}{c}\text { Pounds per Acre } \\
\mathrm{P}_{2} \mathrm{O}_{5}\end{array}$ & $\mathrm{~K}_{2} \mathrm{O}$ \\
\hline \multicolumn{4}{|c|}{ Seedbeds } \\
\hline $7-6-6$ & 28 to 84 & 24 to 72 & 24 to 72 \\
\hline $12-16-12$ & 12 to 24 & 16 to 32 & 12 to 24 \\
\hline Fish & 27 to 54 & 21 to 42 & 3.3 to 6.6 \\
\hline \multicolumn{4}{|c|}{ Transplant Beds } \\
\hline $7-6-6$ & 28 to 105 & 24 to 90 & 24 to 90 \\
\hline $12-16-12$ & 18 to 36 & 24 to 48 & 18 to 36 \\
\hline Fish & 36 to 288 & 28 to 224 & 4.4 to 35.2 \\
\hline
\end{tabular}

These data reveal that in the seedbed, only the high applications of 7-6-6 furnished sufficient nitrogen to meet the full needs of the plants. On the other hand, the low application of all three fertilizers supplied sufficient $\mathrm{P}_{2} \mathrm{O}_{5}$ for all species except Scotch pine, assuming, of course, complete availability which is incorrect. With respect to potash, the tree needs were adequately met by the small doses of 7-6-6 and the large doses of 12-16-12. The high application of fish was adequate for white spruce but not for any of the other species. 
In the 2-0 stock, except for Norway spruce, the amount of nitrogen applied was inadequate from the 7-6-6 and 12-16-12 mixtures; but in the case of high fish treatment, the amount was more than enough, assuming all became available. Medium applications gave sufficient phosphorus; but for potash, neither 12-16-12 nor fish were applied in large enough quantities.

With regard to the proportions of the several nutrient materials in nursery stock, Manchard (7) gives the following data, recalculated by the writer on the basis of $\mathrm{N}=10$ :

$\begin{array}{llccc} & & \mathrm{N} & \mathrm{P}_{2} \mathrm{O}_{5} & \mathrm{~K}_{2} \mathrm{O} \\ \text { Spruce } & 1-4 \text { yrs. } & 10 & 3.4 & 4.9 \\ \text { Scotch pine } & 1-2.6 & 10 & 2.8 & 4.15 \\ \text { Fir } & 1-4.6 & 10 & 3.9 & 5.7\end{array}$

Thus we see that $\mathrm{N}$ is used in greatest amounts and $\mathrm{P}_{2} \mathrm{O}_{5}$ least. The correct proportions to use in artificial fertilization depend upon the amount of available material in the soil.

From this discussion, one may conclude that on sandy soils where an adequate rotation cannot be used and where manure is difficult to obtain, the fertilizer treatment for first year seedbeds should be aimed to supply from 50 to 75 pounds of nitrogen for pines, and 25 to 10 pounds for spruces. Phosphorus should amount to 20 to 30 pounds of $\mathrm{P}_{2} \mathrm{O}_{5}$ for pines, and 20 for spruces: and potash, 25 to 30 and 10 to 15, respectively. For the second year, 100 to 150 pounds of nitrogen, 40 to 60 pounds of $\mathrm{P}_{2} \mathrm{O}_{5}$ and 50 to 75 pounds of $\mathrm{K}_{2} \mathrm{O}$. For the third year, i.e., first year transplant beds, these amounts could be reduced by a third, although if a fourth year is contemplated, the higher amounts would contribute to the fourth year's growth.

\section{DISCUSSION}

\section{Soil Texture and Organic Matter Content}

Nurseries in Connecticut are usually located on sandy loam, loamy sand or sand, laid as glacial outwash terraces or as river deposits. Comparison of the texture and organic matter of the nursery soils at Windsor and Peoples Forest with what Stewart (22) considers to be a good average nursery soil is as follows:

\begin{tabular}{|c|c|c|c|c|c|c|}
\hline & $\begin{array}{c}\text { Coarse } \\
\text { and } \\
\text { medium } \\
\text { sand } \\
2-.25 \mathrm{~mm} .\end{array}$ & $\begin{array}{c}\text { Fine } \\
\text { sand } \\
.25-.05 \\
\text { mm. }\end{array}$ & $\begin{array}{l}\text { Total } \\
\text { colloids } \\
.05 \mathrm{~mm} \text {. }\end{array}$ & $\begin{array}{c}\text { Clay } \\
<.005 \mathrm{~mm} .\end{array}$ & $\begin{array}{c}\text { Loss } \\
\text { on } \\
\text { ignition }\end{array}$ & $\begin{array}{c}\text { Total } \\
\text { nitrogen }\end{array}$ \\
\hline \multirow[t]{2}{*}{$\begin{array}{l}\text { Windsor Nursery } \\
\text { Peoples Forest Nursery }\end{array}$} & $\begin{array}{c}\% \\
40.1 \\
\mathrm{y} \quad 26.8\end{array}$ & $\begin{array}{c}\% \\
48.1 \\
64.7\end{array}$ & $\begin{array}{r}\% \\
11.4 \\
8.9\end{array}$ & $\begin{array}{l}\% \\
8.1 \\
5.4\end{array}$ & $\begin{array}{l}\% \\
3.1 \\
4.5\end{array}$ & $\begin{array}{l}\% \\
0.07 \\
0.14\end{array}$ \\
\hline & $\begin{array}{c}\text { Coarse } \\
\text { sand } \\
2+.2 \mathrm{~mm} \text {. }\end{array}$ & $\begin{array}{c}\text { Fine } \\
\text { sand } \\
.2-.02 \mathrm{~mm}\end{array}$ & $\begin{array}{l}\text { Silt } \\
.02-.002\end{array}$ & $\begin{array}{l}\text { Clay } \\
<.002\end{array}$ & & \\
\hline \multirow{2}{*}{$\begin{array}{l}\text { Good average nursery } \\
\text { soil (Stewart (22)) }\end{array}$} & $\%$ & $\%$ & $\%$ & $\%$ & $\%$ & $\%$ \\
\hline & 36 & 25 & 13 & 12 & 10.5 & $\ldots \ldots$ \\
\hline
\end{tabular}


On the basis of total colloids or of clay, the Windsor soil is slightly superior to the Peoples Nursery soil, although it has somewhat less organic matter. According to Stewart's standards, neither of our nursery soils can be considered as ideal. Seven nursery soils analyzed by Némec (10) ranged in content of fine material $(<.01 \mathrm{~mm})$ from 21 to 41 percent, which is considerably higher than our soils. In another publication (13), Némec reports on eight nursery soils which had an average loss-on-ignition of 6.04 percent, varying from 2.60 to 11.23 percent. In nitrogen these soils averaged .144 percent, with a range of .053 to .344 percent. These figures show a soil condition that is obviously superior to ours with regard to water holding capacity and organic matter content.

\section{Soil Tests to Show Plant Requirements}

From extensive experimentation on a number of different nurseries, Némec (14) (16) reports that, in order to make satisfactory growth, threeyear-old spruce requires a soil containing $250 \mathrm{mg}$. of citric acid-soluble $\mathrm{P}_{2} \mathrm{O}_{5}$ and $160 \mathrm{mg}$. of citric acid-soluble $\mathrm{K}_{2} \mathrm{O}$ in 1 kg., i.e., 250 and 160 p.p.m., respectively. Similar analysis of our nursery soils reveals the following data, with which we include the results by Morgan's Universal method:

Soluble Phosphorus and Potash, in p.p.m.

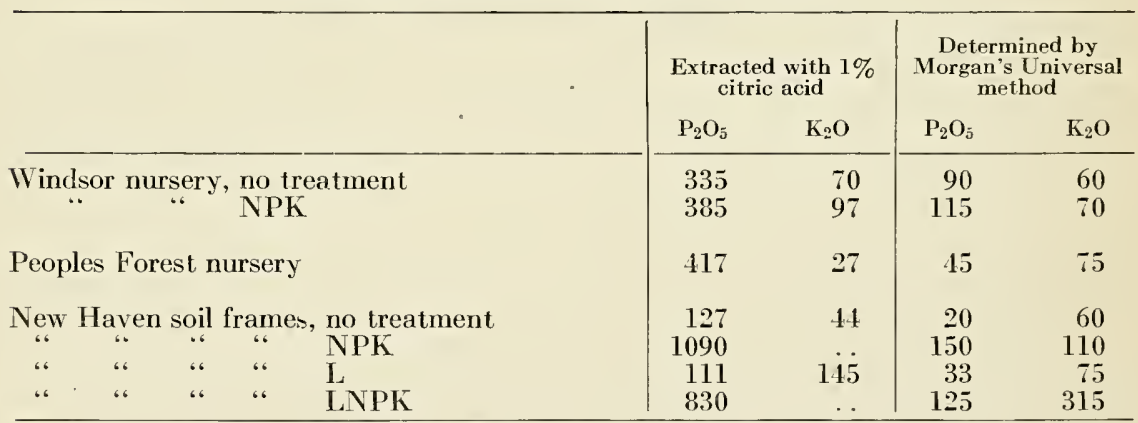

These figures would indicate, according to Némec, a satisfactory phosphorus content, but a deficiency in potash. The untreated and the limed soil in the New Haven soil frames which, it will be recalled, were used for red pines, show a very low phosphorus content, while the NPK and LNPK were very high. Potash was low in the check but fairly good on the limed soil. Potash determined by Morgan's method shows better agreement with the citric acid extract than does phosphorus.

If we use the citric acid-soluble figures as a guide, the foregoing results may explain the relatively low response of red pines to $\mathrm{P}$ and $\mathrm{K}$ in the Windsor transplant beds, Tables 5 and 6 , and the somewhat superior results from $\mathrm{K}$ in the Station soil frame experiment, Table 14.

When the $.5 \mathrm{~N}$ acetic acid method of Stewart (22) was used on the Windsor soil, the values obtained, about 85 p.p.m. of $\mathrm{P}_{2} \mathrm{O}_{5}$ and 30 p.p.m. of $\mathrm{K}_{2} \mathrm{O}$, were low according to Stewart's standards for nursery soil. 
In the use of potassic fertilizers there is some danger of chlorine injury if the chloride form is used on soil containing more than 15 or 20 p.p.m. of chlorine (11) (16), or if large amounts are used on limed soil or on pure sand (4). In our experiments we have generally used the sulfate form, and only occasionally muriate of potash. There have been no evidences of chlorine injury in this work.

\section{Phosphorus}

With respect to phosphorus, Némec (10) found that on soils relatively low in lime and fairly acid (active acidity $=\mathrm{pH}<5.0$ ) there was no noticeable benefit from the application of phosphorus fertilizers. Furthermore, the value of such fertilizer for nursery work is influenced by the water soluble P in the soil and the P-fixing power of the soil. P-deficient soils, showing very little response to $\mathrm{P}$ fertilization as indicated in the growth of spruce, were found to be low in soluble $\mathrm{P}$ and high in P-fixing power (95 to 99 percent of the added P). On the other hand, P-deficient soils which showed response to treatment absorbed only 8 to 23 percent of the added $\mathrm{P}$.

In our experiments, only at the Rainbow transplant beds and at the Windsor soil frames was there a positive response to P and in both cases soil tests showed a deficiency of that element in soluble form. Neither the water soluble $\mathrm{P}$ content nor the P-fixing power was determined.

\section{Nitrogen}

With reference to nitrogen, Némec (12) (1i) found that spruce responded to nitrogen fertilization only where $\mathrm{P}$ and $\mathrm{Ca}$ were present in adequate amounts. He found nitrate of soda most effective on strongly acid soils, $\mathrm{pH} 3.55-4.35$, while sulfate of ammonia was superior to nitrate on soils having a $\mathrm{pH}$ of 4.10 to 4.85 , and was most effective on neutral or alkaline soils.

In our work, sulfate of ammonia gave fairly satisfactory results in the seedbeds and in the first experiment with transplants; but in all other tests it has not proven equal to the organic forms of $\mathrm{N}$. On the coarse sand at Rainbow, the ammonia $\mathrm{N}$ plots were the poorest of all, showing a definite injury as exhibited by high losses and some brown tipping of the needles. Nitrate of soda was always slightly superior to ammonia at Windsor, and slightly less injurious at Rainbow. In the latter instance most of the trees receiving nitrate showed a definite tip burn, in some cases involving the whole tree, which was not the typical reddish brown but rather a grayish white color. This condition was not as conspicuous during the second and third year as during the first. On the whole, urea has been more suitable than ammonium sulfate. This is in agreement with the findings of Kuhnert (5).

In the light of the researches of Mitchell (9), and of the experiences of the superintendent of Peoples Forest Nursery, concentrated soluble nitrogenous fertilizers can be used effectively and in fairly large amounts if applied in frequent small doses, particularily on the seedbed.

In our work lime gave a slight benefit in a few cases, but in others, notably in the station frame experiment, Tables 13 and 14, lime caused a definite retardation in growth of red pine. We know from Tables 17 and 18 that this species takes up less calcium than any other species tested; 
hence, we could hardly expect much of a response to liming. Even with spruce, which requires considerably more Ca than red pine, Némec (18) found that lime was beneficial only on the more acid soils $(<4.5 \mathrm{pH})$ and only when the amount applied reached 45 to 115 percent of the amount necessary to meet the lime requirement of the soil, provided there was sufficient available $\mathrm{P}$ present. On soils containing less than 100 p.p.m. of $P$, lime generally was ineffectual in increasing growth.

Stewart (22) reports that on soils inadequately supplied with P and K, the use of lime may cause an excessive absorption of $\mathrm{Ca}$ and result in browning of the needles. When the several nutrients are sufficiently well balanced, lime can be present in considerable amounts without injury. Stewart is of the opinion that conifers will respond to lime if the lime is used sparingly and in the presence of other nutrients in adequate amounts.

In the light of the more or less general use of lime in Europe, and considering that the soil in the station frames had been limed only once, which occurred about eight years prior to the planting of the pines, it is surprising that the lime had an unfavorable action. It is questionable that the soil reaction by itself was responsible, for in a number of cases the poorer limed plots were just as acid as some of the better unlimed plots. However, it has been observed in experimental work that a, soil treatment which has no effect on the plant in an open plot or in the field may have a decided effect if the root spread is restricted by confining the soil to a pot or box. It is highly probable that the effect of the lime has been accentuated in these soil frames.

\section{Fertilization vs. Root Pruning vs. Wider Spacing}

We have shown that red pine responds to fertilization. Although we have not experimented with root pruning in situ nor with variations in spacing, it is evident from the findings of other workers that the former may result in a shallower, more branched root system better adapted to field planting. Greater spacing unquestionably results in larger individual plants and may permit the elimination of one important and rather costly step in nursery practice, the transplant bed. The writer is not prepared to recommend fertilization over other nursery practices as a means of producing suitable plants. But, regardless of other practices, the fertility of the nursery bed should be properly provided for.

\section{SUMMARY}

Investigations extending over a period of eight years have been carried on to determine the response of coniferous nursery stock, chiefly red pine, to soil treatment with fertilizers. The field work has been confined to three locations: (1) the Windsor nursery, which is a part of the Tobacco Substation at Windsor; (2) the Rainbow forest plantation located in the northwest part of the town of Windsor; and (3) the Peoples Forest nursery in Barkliamsted. The Windsor nursery soil is Merrimac loamy sand rather well supplied with available phosphorus as a residue from previous culture, but low in potash, nitrogen and organic matter. The Rainbow soil is Merrimac medium to coarse sand, low in all essential elements. At 
Peoples Forest the nursery soil is Merrimac loamy sand to sandy loam moderately well supplied with phosphorus and low in potash. The rainfall averages 46 inches, well distributed throughout the year.

In addition to the field work, studies were conducted in soil frames on Enfield very fine sandy loam, very low in available phosphorus; and on Cheshire fine sandy loam, low in both phosphorus and potash in available form.

A prehiminary experiment in butter tubs with soils of a wide range in fertility showed excellent response of red pine to soil fertility.

Seedbed experiments at Windsor and Peoples Nursery indicated, in general, a beneficial effect of fertilizers. Whilc there was considerable inconsistency in response to different materials, there was a tendency for the organic sources to be superior to the inorganic. Undoubtedly the latter are most effectively used when applied frequently in low concentration. High concentrations are very likely to cause severe injury or death.

In transplant beds, if reliable results are to be obtained, it is necessary to hand-select the seedlings for planting. In our work with red pine at Windsor, a general response to treatment ranging up to 46 percent was obtained; but no conclusions can be drawn as to relative merits of the various materials. Concentrations of high analysis fertilizer in excess of 100 pounds of $\mathrm{N}$ per acre were injurious.

At Rainbow, because of the low buffer capacity of the soil. nitrate of soda and sulfate of ammonia used at the rate of 50 pounds of $N$ per acre were injurious to the plants. Again there was considerable inconsistency in response to different materials, although the final measurement of the aggregate height of the trees from each plot placed PK at the top, with 20-8-8, tankage and fish, following closely behind. The application of the fertilizers caused an increase in the amount of available nutrients in the soil as shown by soil tests, but the soluble phosphorus content was increased in much greater proportion than was the soluble potassium content.

At Peoples Forest nursery, although no actual measurements of growth were made, white pine, Scotch pine, Norway spruce, and white spruce showed some benefits from the use of fish meal the first year. In the second year white pine showed some response. In no case were there either outstanding benefits or decided injury from treatment even though applications of fish meal ranged as high as 3,200 pounds per acre.

Soil frame experiments with red pine revealed: (1) at Windsor on Enfield v.f.s.l., a definite response to treatment in overcoming a natural deficiency in the soil; and (2) at New Haven on Cheshire f.s.l., an increase from all treatments containing $\mathrm{N}$, and the best results with $\mathrm{K}$ alone. Growth on the limed series was definitely inferior to that on the unlimed set. The results at New Haven are especially valuable, as the experiment contains a full series of treatments which had been continued without change orer a period of about 10 years. Although the soils varied greatly in content of available nutrients, the maximum difference in size of plants on the best and on the poorest plots did not exceed 42 percent.

Red pine trees which had been fertilized in the nursery showed, in general, somewhat better growth in the field than did the unfertilized trees. 
In the field, fertilization every other year over a period of five ycars has resulted in a slightly increased growth over those unfertilized.

Chemical analysis of nursery trees from Peoples Forest nursery indicates that the requirements of red pine $1-0,2-0$, and $2-1$ stock are, respectively, for nitrogen 41,154 and 84 pounds per acre; for $\mathrm{P}_{2} \mathrm{O}_{5}, 14,32$ and 23 pounds; and for $\mathrm{K}_{2} \mathrm{O}, 18,59$ and 41 pounds. Taking into consideration the density of the stand and the dry weight per unit of area as well as the percentage composition, the total requirements for the first three years of growth were highest for Scotch pine and lowest for Norway spruce.

Although the analysis of the plant shows the amount of material actually absorbed, it does not indicate the fertility status of the soil. Soil tests can show the condition of the soil in this respect if checked with field results. Based upon the experiences of Némec with the nursery soils of Bohemia, our soils at the Windsor and Peoples Forest nurseries are adequately supplied with phosphorus but rather low in potash. However, the studies herein reported do not indicate with any degree of certainty that potash is particularly deficient in these soils.

These studies on nursery stock requirements and response to treatment are being continued and the findings will be reported in later publications.

\section{CONCLUSIONS}

The growth and removal of nursery stock constitutes a considerable drain upon the fertility of the soil which may become serious with continued cropping. In general, red pine and other conifers respond to the application of fertilizers both in the seedbed and in the transplant bed, although in the former case care must be exercised to avoid injury from too high a concentration of soluble materials. Nitrogen is absorbed in the largest amount and should be available in the soil in the ratio of about ten parts $\mathrm{N}$ to four of $\mathrm{P}_{2} \mathrm{O}_{5}$ and five of $\mathrm{K}_{2} \mathrm{O}$. There is indication that the organic forms of nitrogen, especially fish meal and tankage, are slightly superior to inorganic sources; but in the absence of more positive proof, it is advisable to use a mixture containing both forms.

The kind and amount of fertilizer to use must be governed by the quality of the soil, the age of the nursery stock, and to a certain extent by the species. Of the conifers studied, Scotch pine makes the heaviest demands upon the soil, and the spruces, especially Norway, the least. The dry wejght per unit area is a much greater determining factor in nutrient removal than is percentage composition.

On these soils it has not been possible through the use of fertilizers to shorten the period of time necessary for plants to remain in the nursery, but it has been possible to produce somewhat larger plants in the same length of time. 


\section{REFERENCES CITED}

1. Deines, G. Der Forstdungungsversuch, seine Einrichtung und Durchführung. Forstl. Wochenschrift Silva, 18: 365-370. 1930. (U.S.F.S. Transl.)

2. Helbig, M. Einwirkung von Kalk auf Tannentrockentorf. Forstwiss. Centralb. 1910: 271-4.

3. Hilf, H. H. Basaltgrus der Nachhaltsdünger armer Sandböden. Forstarchiv 13: 113-116, 1937.

4. Jessen, W. Über die Wirkungchlorhaltiger Kalisalze auf das Wachstum von verschiedenen Holzarten im Gefässversuch. Bodenkunde u. Pflanzenernähr. 7: 6276. 1938.

5. Kuhnert, O. Kunstdünger im Forstbetriebe. Zeit. Düng. u. Bodenk. 9B: 389$392,1930$.

6. Leiningen-Westerburg, W. Graf Zu. Ủber Düngung im Forstlichen Betreibe. Forstwiss. Centralb. 74: 561-569; 593-602. 1930. (U.S.F.S. Translation No. 201)

7. Manchard, E. Untersuchungen über den Nährstoffgehalt der Aschen forstlicher Kulturpflanzen aus den Halstenbeker Forstbaumschulen. Thara. For'st. Jahrb. 81: 105-158. 1933.

8. McIntyre, A. C. and White, J. W. The growth of certain conifers as influenced by different fertilizer treatments. J. Amer. Soc. Agron. 22: 558-56\%. 1930.

9. Mitchell, Harold L. Pot culture tests of forest soil fertility. The Black Rock Forest, Bul. No. 5, 1934 .

10. Némec, A. Untersuchungen über die Phosphorsäureernährung der Fichte in den Dauerkämpen. Forstwissenschaftliches Centralblatt 54: 5i-69, 88-100. 1932.

11. Némec, A. Úber den Chlorgehalt des Bodens und die Wirkung von chlorhaltigen Kalisalzen auf das Fichtenwachstum in den Forstbaumschulen. Forstarchiv 13: $1-5,1932$.

12. Némec, A. Ergebnisse von Düngungsversuchen in Forstgärten. Ernährung der Pflanze, Berlin, 31: 196-7, 1935.

13. Némec. A. Versuche über die Wirkung der Gründüngung auf das Wachstum der Verschulptlanzen in den Waldbaumschulen. Forstwissenschaf tliches Centralblatt 57: 221-228. 1935.

14. Némec, A. Beitrag zur Kenntnis der Mangel-("Karenz"-) Erscheinungen bei Kiefersamlingen. Forstwissenschaftliches Centralb]att 58: 798-808, 1936.

15. Némec, A. Versuche über den Einfluss der Phosphorsäuredüngung auf das Fichtenwachtstum im Gebiete der Plänerkalkhöden des Revieres Patek A/E. Sbornik Ceskoslovenske Akademie Zernedelske 11: 36-48. 1936.

16. Némec, A. Personal interview, 1937.

17. Némec, A. Der Einfluss einseitiger Stickstoffdüngung auf das Wachstum der Fichte in Waldbaumschulen. Sbornik Ceskoslovenske Akademie Zemedelske, 12: 42-47. 1937.

18: Némec, A. Über den Einfluss des Kalkens auf das Wachstum und auf die Ernährung der Fichte in Waldbaumschulen. Bodenkunde u. Pflanzenernähr. $7:$ : $: 99$, 1938.

19. Schroeder, J. von. Über de Düngung der Saatkampe und Pflanzgärten, mit spezieller Berücksuchtigung des Nährstoffbedarfes junger Fichten. Thara. Forst. Jahrb. 43: 129-156. 1893.

20. Schwappach, A. Forstdungung. I. Neumann, Neudamm. 1916.

21. Sörensen, Hakon. Einfluss der Handelsdünger auf das Wachstum junger Nadelund Laubhölzer, durchgeführt von der staatlichen dänishen Versuchsstatıon Hornum. Tidskrift for planteave, 41: 747- , 1936. (Reviewed in Die Ernahrung der Pflanze 33: 180-183. 1937)

22. Stewart, A. B. Some soil problems in forest nurseries. Scottish Forestry Journal 50, Part 2: 86-92. 1936. 
23. Süchting, H., Jessen, W., and Maurmann, G. Untersuchungen über die Ernährungsverhal tnisse des Waldes. II. Über Nährstoffaufnahme und Nährstoffwanderung in den Organen bei einigen Nadelholzern. Bodenk. 11. Pflanzenernährung 3: 345-368. 1937.

24. Süchting, H. and Jessen, W. Über den Einfluss der Pflanzenernzahl auf den Ertrag und die Nährstoffaufnahme verschiedener Holzarten. Bodenk. u. Pflanzenernährung 7: 14-19, 1938.

25. Toumey, J. W. and Korstian, C. F. Seeding and planting in the practice of forestry. John Wiley \& Sons, New York. 1931.

26. Vater, H. Thara. Forstl. Jahrb. 55: 116-137, 1905. ibid 59: 93-121, 177-212, 213-260, 261-277, 1909.

27. Vater, H. and Sachse, H. Forstliche Anbauversuche Arb. der Deutsche Landwirt. Gesselschaft No. 352. 1927.

28. Wahlenberg, W. G. Experiments in the use of fertilizers in growing forest planting material at the Savenac Nursery. U. S. Dept. of Agr. Cir. No. 125, 1930.

29. Wetzel, A. Der Nährstoffbedarf der Waldbäume. Die Ernährung der Pflanze, 33: 326-329. 1937.

30. Wilde, S. A. Selection of forest litter, duff, and humus for use in forest nurseries. W isconsin State Conservation Dept. and Dept. of Soils, Tech. notes No. 16, 1937.

31. Wilde, S. A. The use of liquid humate fertilizers in forest nurseries. J. Forestry 35: 388-392, 1937.

32. Wilde, S. A. Soil conditions determine success in growing forest nursery stock. Wis. Expt. Sta. Bul. 438: 87-88, 1937. 


$s$

$+$ 
4h. Universily of 14 Comecticut Libraries 


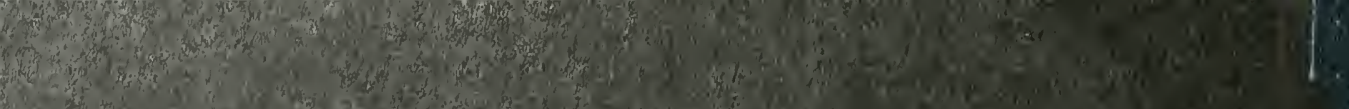
S

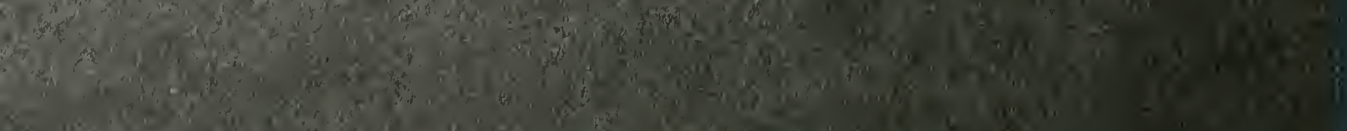
Q (a)

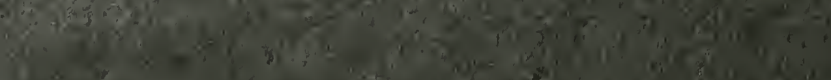

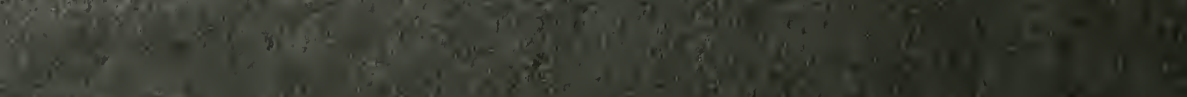

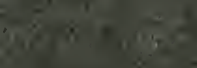

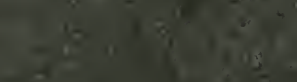

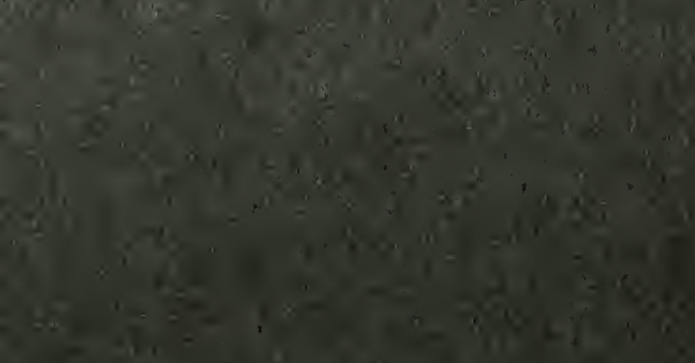

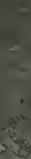

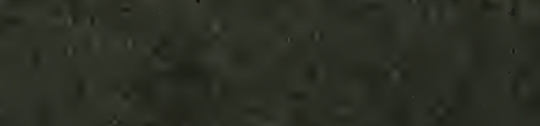

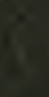

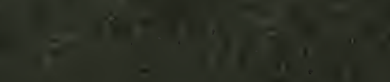

and $3=4$

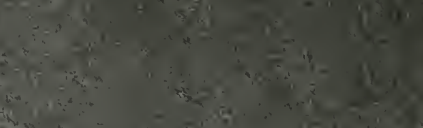

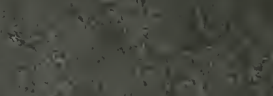

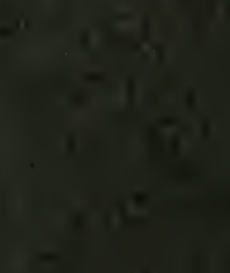
$8+2$ 